CHAPTER ONE

\title{
SONIC HISTORIES IN A SOUTHEAST ASIAN CONTEXT
}

\author{
Bart Barendregt
}

\section{A History of the Popular}

This is a compilation of papers written at various points over the last decade. Some of the chapters were first presented in 2003, as drafts at the workshop 'Southeast Asian Pop Music in a Comparative Perspective', organized by the Royal Netherlands Institute of Southeast Asian and Caribbean Studies (KITLV). Another set of papers has been selected from contributions to a launch event in early 2011 hosted by NWO (The Netherlands Organisation for Scientific Research) for the funded research project 'Articulation of Modernity'. This project analyses the interplay between the production of popular music, shifting ideas of the modern and, in its aftermath, processes of social differentiation in twentiethcentury Southeast Asia. ${ }^{1}$ This event, a workshop held in Jakarta under the title And the Beat Goes On..., was a first venture into what has become the main tenet of our research programme: rewriting Southeast Asia's twentieth century from the perspective of popular music makers, the entertainment industry and its ever changing audiences. Auditory history is also central to this volume. I want to thank all of those who have been involved in the above-mentioned meetings, and also those whose contributions did not ultimately find their way into this volume. This was certainly not due to a lack of insight or engagement with the issues, but rather the fact that they were addressing topics that differed from the main focus of this volume or had less emphasis on long-term transformations.

The study of the popular is vulnerable to a common pitfall; that is to say, more often than not such scholarship is obsessed with the contemporary, the now spectacular, the hip and the novel, at the cost of ignoring the very historical dimensions of such phenomena. Popular music studies

1 Parts of this introductory chapter are inspired by the initial proposal written for this research project, which was co-authored with Peter Keppy and commented upon by Henk Schulte Nordholt and Patricia Spyer. I am grateful to all three for letting me make use of their thoughts.

(c) BART BARENDREgT, 2014.

This is an open access chapter distributed under the terms of the Creative Commons Attribution-Noncommercial 3.o Unported (CC-BY-NC 3.0) License. 
have been no exception, with the majority adopting a synchronic approach and dealing with the present state of things (Hamm 2004). While targeting historical depth here, we realize that the essays presented in this volume provide a necessarily incomplete view of how popular music and associated lifestyles in insular Southeast Asia have developed over the past century. Our project is ambitious in scope; it attempts to cover a whole century of music, starting from the first Southeast Asian recordings made in 1902/1903, all the way through to the mid-200os. At the same time, it tries to offer a glimpse of the current state of the entertainment industry in part of the region (more on the choice and demarcation of the region below). But then, this book promises only a start and the appearance of more historically oriented analyses of Southeast Asian popular music are anticipated in the coming years.

We situate Southeast Asian popular music here in specific sociohistorical settings, hoping that a focus on popular culture and history may shed light on how some people in a particular part of the world have been witnessing the emergence of all things modern. We are obviously not the first to do so, although our very focus on the modern in relation to the popular and new social formations may be perceived as innovative. ${ }^{2}$

A historical approach to popular culture has been manifest ever since the 'cultural turn' in history; 3 an interest which may be traced to early publications such as those of Hobsbawm (1959) on the Jazz Scene, its publics and the larger economy the music was part of. His and other works break with the 'drum and trumpet' history then current. They dismiss its sole focus on the political and the economic while neglecting culture, and leaving out ordinary people altogether. In its stead, a 'history of below' (cf. Samuel 1981) is advocated that prioritizes the local rather than the national, prefers the domestic over the public and the popular over the state. Clearly, an interest in popular culture and history also has its parallels, even forebears, in other disciplines such as sociology, art history, anthropology and literature studies, and may be said to have culminated in the early 1960 s into the new field of 'cultural studies'. Hogart, Thompson

\footnotetext{
2 At this stage it is necessary to recognize the pioneering work of a number of historians working on the region itself, including the likes of William Frederick (1982) and especially Craig Lockard's (1998) Dance of life. Like the present work, Lockard targets a comprehensive view of the region that, in fact, is even more inclusive than ours here. However, his work specifically addresses cultural politics and is, overall, more concerned with artists and producers than with audiences and consumers, or the wider industry they are both shaping and shaped by.

${ }^{3}$ See Burke (2004) for an overview.
} 
and Williams were interested in the tremendous postwar transformations of class-based English society and, in historically tracing these changes in the everyday domain, they tried to recover the experience and agency of a majority normally ignored in academic discourse. In their view, a study of 'plebeian, 'mass' or 'popular' culture made no sense, unless studied over a considerable historical period and thereby paying due attention to the larger structures they were part of, although opinions clearly differed over the extent to which the popular classes shaped or, rather, were bearers of such structures. ${ }^{4}$ Questions about the extent to which man is able to make his own history increases once the focus moves to eras closer to our own (and in contrast to the seventeenth and eighteenth century working class cultures often studied by these early 'popular historians'). With the huge shifts in (media) technology and the rise of cultural industries from the 1920 s onwards, popular culture is at once very different from the commonly shared practices preceding it. ${ }^{5}$ Some of these transformations have been chronicled by later cultural studies scholars such as John Storey (2003), who shows how the concept of popular culture, once invented in the late eighteenth century, went through various stages and has been adapted to different means and for various political agendas. But overall, historical studies of the popular still tend to be few in number, Eurocentric in character and mostly focus on specific time frames. In addition, much of what today lives by the name of cultural studies has become notoriously ahistorical. There are favourable exceptions though, and the work by authors such as Grossberg, Gilroy and Lipsitz strongly emphasizes the importance of looking into history when studying the popular. Grossberg's (1992) We gotta get out of this place, for example, illustrates how rock music may be treated as a way into relations of culture and power in postwar USA. A historical study of rock culture, a genre conventionally depicted as transgressive and subversive, may help to understand it as part of the particular American liberal consensus model so prevalent after the war, in which

4 For a discussion of various approaches to structure and agency in these cultural studies, see Hall (1980).

5 The term 'popular' originally designated the notion of 'belonging to the people'. Various authors have problematized the notion; among them Peter Burke (1981) who states that once the people or the popular are deemed to become everyone minus an elite, we run the risk of homogenizing our analytical categories, thus shaping a singular popular culture that seemingly works for all. Raymond Williams similarly acknowledges the reifying power of concepts such as 'the popular' or 'the mass', which retain negative connotations of the low, the vulgar and thus relegate the majority of society to a mob status. A more neutral interpretation of popular culture, then, is that of 'widely appreciated', and 'away from a top-down perspective,' referring to people's own views (R. Williams 1976). 
youths appropriated music to indeed challenge but also perfectly stay within the constraints of this ideological formation. Also Lipsitz' (2007) 'hidden histories of popular music' do away with conventional American historiography and its emphasis on the modern metropolis, nationalism and individual genius. In its place is a focus on rural communities, black subaltern conscious and other temporalities, spaces and subjects hitherto silenced in mainstream history. Furthermore, culturalhistorical approaches have been taken up by music scholars such as DeNora's (1997) work on the social, organizational and cultural structure of Vienna's musical world during the 1790s, or the essays collected in the Popular Music History journal (since 2004). Worthwhile mentioning in this respect, is pioneering work of a more popular scientific character, including the works by Greil Marcus (1989) on 'pop's secret history' and John Leland's (2005) 'history of Hip', both of whom manage to show how a focus on popular music may indeed provide us with alternative readings of the past.

The idea for the current compilation is clearly inspired by some of the works mentioned above and sets out to do what has become the central tenet of our Leiden based Articulating Modernity project; studying Southeast Asian history by means of focusing on popular music practices. The times are a-changing, is an important motif of (also) many of the Southeast Asian songs described in this volume, and we strongly believe that these songs and sounds, the singers and musicians that performed them, the audiences they addressed, and importantly the musical life worlds they were simply part of, can tell us something the official history of the region often cannot. This introduction, then, serves to signal some prominent themes and trends in the historical ethnography of the popular in Southeast Asia's twentieth century and to connect the various essays to the volume's major topics: the modern, the popular and emergent social formations throughout the Southeast Asian region. Let us first explain why we think modernity as a discursive concept is so beneficial for our understanding of Southeast Asia's twentieth century.

\section{Modern Sounds}

Modernity constitutes a dynamic field of practices and ambivalent understandings regarding progress, social change, novelty, technology, and human agency. Rather than an essentialized Euro-American model of modernity, from which other 'second' or 'incomplete' modernities derive, we aim here to track distinct genealogies of modernity, much in line with insights from the emergent field of alternative or multiple modernities 
(e.g. Gaonkar 1999; Eisenstadt 2000; Hefner 1998; for more recent discussions, see Wagner 2012). However, in offering concrete case studies we hope to move beyond the sometimes meagre conceptualization of what the modern stands for in such alternative schemes. ${ }^{6}$ We do so by studying modernity relationally and situationally within localized and time-bound debates (Geschiere, Meyer and Pels 2008), investigating what words were being used in daily discourse, what it looked like and especially what it sounded like to the men and women in the street and back at home. Similarly, popular songs 'may be principally about personal feelings and relationships, but these may be conveyed by description and by analogy, in contexts relating to place and time, youth and age, aspiration and rejection, hope and nostalgia, peace and war, success and failure. They also draw upon the material world, whether it is one historically of bicycles or automobiles, telephones or typewriters' (Oliver 2004:17).

This volume's innovation lies in investigating the articulation of modernity through popular music in the context of two transitional periods in modern Southeast Asian history: from the late colonial state to recent nation states (i.e. 1920s-1960s) and from the heyday of authoritarian rule to emergent democracies (roughly 1970s-200os), although the outcome of these transformations clearly differs from one society to the other. Conventional historiography of the region usually concentrates on particular periods. For Indonesia, for instance, this implies a segmentation of history into 'the late colonial period', followed by the 'Japanese occupation, 'the Revolution' and 'Independence'. Recent history writing focused on Indonesia, the largest country under study here, tends to differentiate between the period of the New Order, followed in 1998 by a separate era called Reformasi. The problem with such compartmentalization is that it obscures complex processes of continuity and change extending from one era to the next, and it is too much driven by state formulated agendas. ${ }^{7}$

6 Traditionally, Multiple Modernities scholars have been interested in variation and continuity, criticizing what they see as the acultural idea of convergence held dear by many modernization theorists. The latter, mostly following the work of Talcott Parsons, have stressed the fundamental difference between the key institutions of a premodern and modern formation, while being less interested in cultural or geographical variety as such. Volker Schmidt (2010) rightfully points out that, in fact, both paradigms focus on different (though related) phenomena, with adherents of the multiple modernities paradigm being better equipped to study the cultural variation that we also propose to do here, rather than looking at varieties within the political sub system as, unfortunately, most of such studies have done so far.

7 An alternative approach was successfully practiced by the NIOD Institute for War, Holocaust and Genocide Studies project Indonesia Across Orders that focused on political and economic transitions from the 1930 s to the 1950 os (Lindblad 2008). 
Recent historiographical work on Southeast Asia's twentieth century has not surprisingly started to problematize such nation-centred narratives, trying to capture border crossing ideas and including actors that may have been politically or economically marginal to the work of history but were by no means insignificant from a cultural perspective. The central thesis of such work is that for many Southeast Asians entering the postcolonial era, it is the appeal of 'modernity', more specifically 'modern lifestyles', rather than the sort of abstract notion the nation state usually is to many. ${ }^{8}$ Joel Kahn $(2001,2003)$, for example, urges us to move away from the 'exemplary modernity' as formulated in governmental agendas or intellectualistic debates, instead paying due attention to alternative conceptions of modernity as they surface in the realm of the popular and the everyday. Struggles over the meanings of modernity, he argues, are nowhere as explicit as in the realm of the entertainment industry. In its constant urge to produce ever new fashions, lifestyles and markets, we find a glimpse of how and why people have taken up ideas of the modern, how it is made, unmade and remade, paying ample attention to how such reconfigurations may serve various claims and are constantly haunted by yet others.

Studies of fashion and gender in Asia show how people experimented with the new and modern just as early as Europeans did (Weinbaum et al. 2008; Schulte Nordholt 2009, 2011; Taylor 2012). Similarly, two fascinating accounts on jazz in East Asia by Jones (2001) and Atkins (2001), ${ }^{9}$ do away with the myth of the appropriation of US jazz as just a token of belated modernity. Rather, they show that Chinese and Japanese artists and entrepreneurs experimented with jazz almost simultaneously with their peers in the West, thus localizing and authenticating what was considered by all means a modern genre. Focusing on popular music, then, may offer insights into the particular historical trajectories of modernity in specific urban settings, unravelling what Hildred Geertz (1963) dubbed in relation to Indonesia as the emergence of a new 'metropolitan superculture'.

Illiteracy rates in Southeast Asia were long high and it seems that through mass media, audiovisual technologies, the gramophone, radio,

8 That said, Southeast Asian nation states have generally been quite successful at monopolizing the meaning of what is to be considered modern or not, using amongst other things extensive development programmes, state-run media and iconic technologies to convince citizens to be part of what increasingly is a secular neoliberal future.

9 See also Peter Keppy's forthcoming work on Southeast Asia's 'jazz age' within our Leiden project. 
television, cinema, audiocassettes and CDs, music reached larger, more socially differentiated audiences - even across national borders - than print media did. Music, by its nature, is suitable for expressing new styles while simultaneously connecting the familiar with the new, the foreign with the local (Adorno, Leppert and Gillespie 2002). So popular music is made to sound modern through articulating different musical elements into novel forms. This can be by the use of new technologies, but also by hybridization. Philip Yampolsky, in his chapter to this book on colonial radio in the Dutch East Indies, argues it is especially the incorporation of elements of the European and American ('Western') popular music of the 1920 s and ' 30 s that then qualified a music as being modern. These elements may have consisted of specific songs or dance rhythms that were popular at the time, the common-practice harmony, or arrangement styles of Western popular music, but making Indonesian music modern by all means was to fuse it with Western popular music. A modern instrument meant Western instruments, and clearly many supposed that modernity was something triggered elsewhere. Talking about New Order Indonesia of the 1970s, Baulch still notes a similar equation of aesthetic Westernization with the novel and modern. Her contribution is one among many in this volume pointing at the sheer enthusiasm with which foreign ideologies and values have been adopted by Southeast Asia's popular music makers (although similarly enthusiastic others have, at times, tried to resist them; more on that below).

Music genres represent historical continuity and stability, and mark common training, aesthetics, techniques, skills and performance practices (Weintraub 2010:12). But equally, throughout the twentieth century, mediatization and hybridization of musical styles and genres triggered debates on what is regarded as authentic and traditional. ${ }^{10}$ Sometimes the use of new technology led to what appeared to be completely new sounds, as is the case with the pop yeh yeh sound so prominent in 196os Malaya and Singapore. In the aftermath of marked changes in the sound of English popular music of that time local music acts preferred amplified bass, drum and especially electric guitars, in what elsewhere was also known as ku-gi-ran (kumpulan gitar rancak, or 'upbeat guitar' bands). Both J. Tan (2011) and Pereira (2011), as well as Johan in his contribution to this volume argue that Singapore performers promoted themselves as the latest

10 See Weidman (2003) for an example on India; that such discussions continue into the present is attested by the studies of Baulch (2007) and Wallach (2008). 
thing, and it is this self-conscious modernity that at that time was very much seen as the expression of a new culture. For example, new venues, changes in dress styles and other aspects of youth culture, new bands, new genres, and new responses are all a feature of music in Singapore during this period. At the same time, and we cannot overemphasize this, Singapore musical culture of the 1960 s can be very much viewed as a modernized version of previously popular street entertainment and the amusement parks, as described, for example, elsewhere in this volume by Van der Putten. Most of the time, then, 'the modern' as an achieved, rather than inherent state, is defined by what it is not or what is now deemed obsolete, as Wallach also argues in his contribution. Musical genres do not operate in a vacuum and are constantly recreated and changing with newer and more modern styles being contrasted with preceding, more 'traditional' versions. But as Yampolsky rightfully remarks: in most cases no one actually seems to know what the original repertoire or style was. One knows only what people did within living memory, or what is thought to have been earlier practice. The concept of 'authenticity' may, therefore, be of little relevance to our studies of twentieth century popular music as it is the very same processes of hybridization, change and continuity that deserve our attention (see Van Zanten, this volume).

Next to hybridization and the appropriation of Western sounds and aesthetics, most contributions in this volume note the equation of both the modern and the popular with mass media, being the indispensable means of dissemination of popular music. A brief look at the emergence of Southeast Asian entertainment industries may very well explain why.

\section{The Entertainment Industries}

Empirically, the study of the popular is one of pioneering creative artists who straddle conventional categories of ethnicity, religion, gender, generation and class, and of their audiences. Mobilizing cultural resources and networks, and exploring technological and entrepreneurial possibilities, these artists are at the forefront of popular culture's production and redefinition. However, artistry alone will not popularize songs as it is capital, expertise and ongoing facilities that are central and a means that, until very recently, only an industry could provide. A music industry based on the marketing of recordings as mass commodities therefore plays a crucial role in popularizing music (see also Manuel 1993:4; Chun and Rossiter 2004). As early as 1902, representatives of the early 
entertainment industry started to collect recordings by local performers in parts of Southeast Asia. ${ }^{11}$ Western multinational gramophone companies aggressively opened up consumer markets in Southeast Asia, using local brokers to sell equipment and musical recordings. Such aggressive competition for popular music markets has endured and has its equivalent in today's rivalry between some of the world's largest cultural content providers aiming for a share in the profitable Southeast Asian market. Record companies may be notoriously conservative, but they are quick to react once they discover the potential of new markets. Laird (2011) has described the industry's initial reluctance to Singaporean adaptations of Western rock and roll. It was not until 1963 that any record company decided to release a record by a Singapore guitar band. However, from then onwards, the Singapore record industry boomed and between 1965 and 1969 over 120 different labels released local recordings; a figure not even including long established labels such as Columbia, Pathé, Odeon, or any of the numerous labels based in Malaysia, Indonesia, Hong Kong, and other neighbouring countries which were also catering for the Singaporean market. Elsewhere in this volume, Baulch describes how in the second half of the 1990s their heirs, Sony Music, Warner, EMI, BMG and Universal, all established offices in the Indonesian capital Jakarta, and encouraged the across-the-board adoption of a royalty system, which now governs contractual deals between recording artists and recording labels worldwide. Such globalization of popular music practices has changed the ways performing arts are experienced by many Southeast Asians today.

Whereas popular music cannot be seen separately from the larger political economy it increasingly became part of it during the twentieth century, its history is importantly one of innovative use of new technologies, technologies that are often pioneered by the happy few and those with sufficient access to social, cultural or economic capital. Driven by the new media technology of the gramophone and the arrival of new musical genres such as jazz, Latin music and local hybrid variants thereof, the very first popular music celebrities and local entertainment industries burgeoned in Batavia, Singapore and Manila of the 1920s (Möller 1987; Cohen 2006, 2011; Keppy 2008; Yampolsky 2010).

Unprecedented opportunities for disseminating new music, offering professional careers in entertainment and creating new audiences opened up in the 1930s with the radio, a topic also dealt with in Philip Yampolsky's

${ }^{11}$ For more detailed studies, see Gronow (1981); S. Tan (1996); Suryadi (2006). 
contribution to this volume. ${ }^{12}$ Published studies of radio in the Netherlands Indies before World War Two have focused mainly on the politics of colonial radio: on the administrative structure of broadcasting and its political implications. While starting from such a struggle, Yampolsky examines in more detail the live broadcasting of music (and theatre) on the radio. He does so by focusing on one full year, 1938 (chosen simply because it is the year for which available documentation is most ample). A central question of his research is the extent to which government-backed radio broadcasting differed from that of private, and to what extent the private stations differed amongst themselves when it came to highlighting the arts. Yampolsky argues how radio, with its dependence on good musicians, was more strongly conditioned by its physical locations than were records. However, radio was also more flexible in exploring new talent. Nevertheless, radio tended to be surprisingly conservative in its interests, often aiming to maintain the prestige of particular 'high art' genres; while the gramophone industry simply sought what sold. Yampolsky's radio research also allows us to consider the position of radio, and in particular radio music, in the great issues that were in the air in the 1930s: modernity, nationalism, the relations between colonizer and colonized (with radio failing to bridge the gap between its Eastern and Western listeners) and the development of a pan-Indonesian culture through what had become the urban folk music of Batavia, kroncong.

Did radio and gramophone usher their audience into the modern age, Yampolsky rightfully wonders, referring to the big paradox of a new medium that was modern and made arts accessible to the many, yet the contents of which were sometimes utterly conservative. For sure radio and recordings changed the ways music was listened to and, as commodities, they were especially able to provide a new emergent Southeast Asian bourgeoisie with a prestigious, standardized, and often sanitized version of what hitherto had been available to the bohemian chic, or was otherwise hidden in the underbelly of Southeast Asia's entertainment quarters. ${ }^{13}$ Radio catalogues and record sleeves emphasized the prestige and novelty of such recorded music and the advertising of records,

12 On radio's early beginnings in Indonesia, see Mrázek (2002) and Lindsay (1997).

13 Mutsaers mentions the connection of opium revenues and the entertainment world of stamboel and kroncong, as well as the bad press regarding morals among artists. As Mutsaers argues: 'Prostitution and money lending, attracted adventurers from all walks of colonial life and discouraged polite society from attending this home-grown form of entertainment' (Mutsaers 2013). For an Indian equivalent of such stigma attached to early twentieth century entertainers, see Farrell (1999). 
gramophone players and radio sets on a par with other icons of modernity, such as soap, light bulbs and cigarettes, they similarly provided access to a new cosmopolitan world out there.

In an era of dramatic economic, social and political upheaval in which Southeast Asian societies were intensely transformed, mass media recordings helped popularize music. Not surprisingly, such recordings capture much of how these profound changes were imagined and perceived of at home and in the new-born public sphere these media were part of. New venues for performance and musical consumption developed in the period 1920s-1950s, where people socialized and relaxed: movie theatres, fairs and dance halls. Importantly, well into the 196os, popular music in particular was music for social dancing. In his contribution, Jan van der Putten describes how, in colonial Malaya, Chinese transnational capital was largely responsible for the development of amusement centres where a wide range of entertainments - from Teochew operas to wayang kulit, boxing matches to ballroom dancing - was made available (supposedly) to everyone: entrance fee was only $5^{-10}$ cents, but extra fees applied if one wanted to watch a movie, theatre play or dance with one of the Malay 'taxi girls' waiting for customers of all social standing and background. These parks are considered to have been melting pots of different ethnic groups and provided entertainment to all cultures with their respective popular forms. More often than not, musicians performing at such venues had more than a single patron and besides performing at live 'events' they were also for hire and provided music to other sectors of the entertainment industry, such as the cinema orchestras or local gramophone companies featuring recording artists before the films were screened in cinema halls (S. Tan 1996). Wider circulation of cinematic contributions to the popular music industry and further exchange between these domains is a topic that merits further study, ${ }_{1}^{14}$ but what we do know is that some of Southeast Asia's main pop icons would move on to make a career in the local film industry. These include the likes of Roekiah and Rd Mochtar (of Terang Boelan fame, 1937), Rhoma Irama, Benyamin S. and Malaysian superstar P. Ramlee..$^{15}$ Because many of these musical movies

14 For a present day study of the impact of Hindi film songs and local appropriations thereof, see David (2008).

15 On the 1970s Betawi B-movies and songs of Benyamin S., see Hanan and Koesasi (2011). For Rhoma Irama and the world's 'first Islamic rock musical motion picture', see Frederick (1982). Finally the life, films and songs of P. Ramlee are described in a growing number of studies, including those by Sarji and Johari (1995), Harding and Sarji (2002), Syed Muhd Kairudin Aljunied (2005) and Barnard (2005, 2009). 
were filmed on location in Indonesia, Malaysia or Singapore, they provide us with a window on those places in particular time frames, and they also offer a glimpse of how the global aesthetics cinema brought in were profoundly localized in sight and sound.

Similarly, the topic of the development of the music industry in Malaya and Singapore in the 196os, taken up by Johan here, provides a case study for examining the various changes and developments that were common throughout the entertainment industry internationally at that time, but more often than not had a very local impact. Johan's chapter illustrates the shift away from film as the once dominant technology of disseminating Malay music to the guitar bands so heavily plugged by an emergent local record industry. This transition to a large extent explains the reactionary comments of former film stars such as P. Ramlee, who soon was to be replaced by louder sounds and a less conservative Western oriented fashion. Ramlee's Malay traditionalism was not part of but worked in tandem with conservative state policy which condemned what it saw as foreign and subversive. The result is a complex but fascinating account of how both musical culture and changes in the industry influenced and conflicted with other significant forces concurrently sweeping through Asian society at a crucial time in the development of Southeast Asia.

As outlined, new media technology enables new ways of making music, connecting hitherto separate musical traditions and introducing new styles and sounds. In the 1970s, cheap cassette technology (cf. Manuel 1993) allowed musical entrepreneurs to re-engage localized forms of identity, offering a platform for ethnic and traditional genres that industries previously had ignored (for more on this, see below). Cassette technology also offered groups and individuals disenchanted with nationalist visions of modernity in Southeast Asia a means and platform to voice discontent. My own research on the use of cassette technology by Islamist revivalist groups such as the Malaysian Darul Arqam (1968-1994) is a case in point (Barendregt 2012). Through its home-based OVA studios the movement released hundreds of (video) cassette lectures, Malay language comedy, but also popular Islamic nasyid songs that helped spread the Arqam message well beyond its model villages. Again, there is no single trend here. Ethnic and religious niche markets may profit very well from such new affordable media technologies, but equally Baulch (in this volume) remarks how, in the 1980s, due to the advent of cassette technology, the trade in Western pop for some time became far more lucrative than that of local pop forms, as the latter included far higher production costs. 
Western pop could simply be re-recorded as the production costs were borne elsewhere and thus, for a considerable time, put local pop on a second level. ${ }^{16}$

\section{Changing Access, Listening Experience and Taste Makers}

Technology, then, importantly determines access, although this access may take an unusual shape in countries that until recently were considered merely to be downstream markets for other more powerful culture industries elsewhere in the world; markets that could only participate in modern forms of cultural expression by seeking resort to copying, piracy and other forms of 'cheap globalization'. Pirated products are widely considered to be destructive for musical scenes, such as was the case for Singapore in the early 1970s. Here, according to estimates, in some cases sales of legitimate releases were severely affected and up to $5^{\circ}$ per cent of record sales by the more popular artists could be lost to pirates (Laird 2011). However piracy is not always and everywhere equally regretted by artists themselves, with today some of the most famed artists in the region, including dangdut singer Inul Daratista and Lampung based pop act Kangen band, deriving much of their success from such acts of piracy. Illegal content or, as Baulch prefers, 'unofficial (versus official) content' (cf. Heryanto 2008) is especially facilitated by new means of digital reproduction, sharing and distribution that have run rampant all over Southeast Asia. However, in her research for the Articulation of Modernity programme, Nuraini Juliastuti argues how many of these practices seen as harmful to and situated at the fringes of the industry, more properly can be defined as part of that very same industry (see also Baumgärtel 2012). They are to be approached as knowledge-seeking techniques and a prerequisite for the modern project so longed for by many young Southeast Asians. Even the industry itself increasingly approaches YouTube wannabees, mash up DJs and lip sync artists for something that it seldom does: innovatively contribute to popular culture. Some of them even get offered lucrative record deals by that very same industry. Hence, the pirate may become a gatekeeper and local taste maker.

16 And not until the 1980 s did pop Indonesia became a more serious contender, commercially speaking, as those recording labels that had hitherto devoted their attention to re-recording Western pop recordings began to upgrade their interest in developing pop Indonesia repertoires. 
Novel sharing and distribution mechanisms have enabled a thriving DIY scene in most Southeast Asian metropoles and especially student towns (Luvaas 2010; but see also Gjelstad, in this volume). Gjelstad hints at the sudden popularity of the distro, an abbreviation of distribution store, which is related to this significant shift in Indonesian popular and youth culture - a reorientation from hyper-commercialized brands to independent designers making T-shirts in limited numbers and distributing them to small shops. The designer, like the DJ, has become a new and prominent kind of artist on the Southeast Asian youth scene. Musically, this DIY scene seeks its inspiration in hitherto little tapped sources such as industrial, techno, Brit pop-like Indie music and other niche markets, although metal and punk rock music have a much longer tradition in most Southeast Asian countries that may be traced to the earlier democratizing workings of cassette culture. ${ }^{17}$

To a large extent, technology also determines the ways music has been listened to. From the early wax cylinder carried by the sonic explorers of the early twentieth century, to the bodily sensations caused by the public PA of mega acts such as Gong 2000 or Soneta described by Weintraub (2010), there have been some profound changes with music moving from the very public into the private sphere and back again. ${ }^{18}$ When the first record players went on sale, music was an exclusive commodity, available only to the happy few. Radio, while still expensive, would in time broaden this reach, as did cinema and even more so cassette technology. Today, Southeast Asian music, as elsewhere in the world, is mostly listened to through digital devices such as MP 3 players, phones or through platforms such as YouTube, MySpace or Spotify. What such changes do for the individual listener and in relation to other listeners remains largely terra incognita. In this volume, Lars Gjelstad describes how through playful cultural practice in their bedrooms and with their home equipment, boys are creating cultural identities based on cultural models of cosmopolitan nightlife offered by the local music bar they frequently visit. According to him, bedroom practices such as tape compilations, musical diaries or selfconstructed dance floors have to be understood as moments in a wider 'circuit of the production, circulation and consumption of cultural

17 Independent labels in fact date back much longer. Laird mentions a mushrooming of independent labels in 1950s Singapore, for example. On the Southeast Asian metal scene refer to the accounts of Yusof (2009), Wallach (2011) and Dairianathan (2009, 2012). On punk rock, see Pickles (2001) and Baulch (2007).

18 For more on the impact of foreign technology on ways of listening in Java, see Sutton (1996). 
products'. From the cafés, his young informants bring the music and its cosmopolitan atmosphere back to their private bedrooms. The taste and competence acquired in these informal spaces are then fed back into the cafés by way of dance performances and by requesting their favourite songs from local and national Top 40 bands.

Finally, the sheer materiality of media technology itself, such as the gramophone player, radio, and more recently $\mathrm{MP}_{3}$ devices and mobile phones, have throughout the twentieth century developed into indicators of the social status of its owners. As such, Baulch's essay refers to the recent upsurge of mobile content providers, which have lately emerged as the new independent players in the industry. Today, most revenues for popular performing artists are retrieved not from gigs, concerts or merchandize, but from the royalties on ring and ring back tones. Access, new ways of listening and social status converge here. The ring back tone is inexpensive and easily downloadable, even to those living in the rural hinterlands; it can be played and listened to in the private bedroom, but it is primarily meant to be overheard in public and thus serves to signal the owner's social and cultural capital.

One cannot overstate the importance of technology for the popular music industry, but one should simultaneously take care not to simply mistake one for the other. While recordings are an important means to discover what was popular in both the 1930s and 196os, both Yampolsky in this volume and Laird (2011) warn that actually much passed unrecorded. ${ }^{19}$ Media technology, then, is only one (very important) way in to the complex and very fragmented history of what is an ever emergent industry. Following the lead provided by Williamson and Cloonan (2007), it may even be more apt to speak of 'entertainment industries' in the plural. There is no such thing as a single music industry. There are, however, people working in a range of industries centred around music. In line with Small (1998), we are also inclined to include all aspects of 'musicking' here into our analysis, focusing not only performers, producers and audiences, but also on those involved in other popular music related sectors such as design, distribution and, not to be neglected, journalism and other taste making practices.

19 This does not even include gendered ways of consumption, a relevant but hitherto hardly researched topic. Wallach (this volume) stresses how dangdut performance is a mostly male domain. But dangdut is not just a performed music; it also exists on recordings that can be used in private listening encounters. In his research he found that ordinary Indonesian women frequently listened to dangdut cassettes, and, in fact, probably make up a majority of the consumers who purchase such cassettes. 
Importantly, popular music cannot be understood as separated from the particular moral climate it was part of and wider discussion of what entails good or bad, high or low taste. In this volume, Jan van der Putten describes how it is likely that a cosmopolitan, hybrid and wild aura of cultural practices distributed through the 1920/30s amusement parks was incompatible with the more parochial and modest identity based on ethnicity and religion as promoted by the Malay intelligentsia and popular press. As an example, he quotes several articles from newspapers that were predominantly Islamic reformist in character and had their own particular cultural agenda, to which the popular arts and music had to be subjected. Today, print and more recently online journalism still fulfil a similar gate keeping function. In her contribution, Baulch refers to the tremendous success of pop Melayu in the early 200os, much to the disdain of cultural critics and journalists who underline Pop Melayu's lack of modernity as opposed to the more cosmopolitan sounds of pop Indonesia or, for that matter, Western pop. Pop journalism may even be formative in shaping audiences itself. Baulch thus shows how print media have played a crucial role in endowing literate Indonesians with considerable cultural authority to class-ify genres and, by extension, in building, and continuously reinforcing a myth of a 'middle class', reading public as a truth bearing public. The devaluing of some Southeast Asian and supposedly utterly un-modern genres, such as dangdut and Pop Melayu, may be understood as integral to such myth making. ${ }^{20}$ At the dawn of the twenty-first century, the Southeast Asian entertainment industries are intensely changing and 'new modes of knowledge production' and new 'mediating ideologues' have emerged from the coinciding of socio-political changes with wider developments in the mediating technologies outlined above. One of them is the - to the industry increasingly important - figure of the A\&R executive. Baulch recognizes that while new valourizations of such executives do appear to draw on older patterns of producing intellectuals hitherto known to the Southeast Asian entertainment industry, they are also increasingly facilitated by global patterns of staging production,

20 In a similar vein, Baulch (2010) examines how Rolling Stone Indonesia as a magazine addresses a predominantly 'male, discerning, reading public', with the magazine itself drawing directly from styles of journalism developed in the 1970s to engage a similar group. 'Rolling Stone's attempts to emulate this journalism may be read as a calling back into being the middle class subject whose features were considerably sharpened in the new political environment of the 1970s' she states. For other studies dealing (partly) with Southeast Asian pop journalism, see Siegel (1993, especially Chapter 8) and Scherer (2006). 
patterns to which transnational recording companies are contributing. A\&R executives, critics, journalists and other taste makers, as she concludes, engage developments in the media environment to propose novel formations of modernity.

\section{The Making of Musical Lifestyles: Fans, Hierarchies and Transgression}

Music's commoditization by an entertainment industry does not in itself explain its popularity. In our Leiden based project we connect popular music with the emergence of new audiences recognized by distinct lifestyles, which in turn opens the possibility of exploring processes of social differentiation. The phenomenon of lifestyles has been an integral feature of modernity (see, for example, Chaney 1996). By providing audiences with fashionable styles, social identities are made visible and audible through the consumption of popular music. In this regard, most of the essays in this volume also aim to investigate the extent to which notions of ethnicity, religion, class, gender, generation or other forms of social distinction play a distinctive role in articulating popular music and lifestyles. Following DeNora (2004), we analyse how the social dimensions of popular music are articulated in specific contexts. Articulation means to express as well as to create connections among different practices or elements, resulting in new shapes and meanings. Articulation as formulated by Hall (1986, 1996), and developed in the music studies of Middleton (1990) and Grossberg (1992), enables us to further negotiate the historical and sociological dimensions of popular music. Theories of articulation are 'attentive to how a plurality of voices sometimes harmonize and sometimes argue, how diverse speakers link various tropes and images from more or less common sources to announce competing claims' (Johnson 2008).

People actively use music to mark 'us' versus 'them', positioning themselves in moral, political, and aesthetic (stylistic) terms and empowering themselves within social hierarchies (Barber 1997). Popular culture in Southeast Asia is similarly a cultural construct of social groups who may use it to symbolically mark important social distinctions (Pinches 1999; Chen and Chua 2007; Heryanto 2008).

The most talked about distinction in this volume is without a doubt that between the urban progressive (gedongan) and village backward (kampungan) lifestyles (see also Weintraub 2010:226; Wallach; Baulch, both in this volume) as present in many Indonesian popular expressions. Wallach relates how in Indonesia, the Suharto regime's (1966-1998) 
commitment to 'progress' was fuelled by foreign investment and the importation of consumerist desires for an emerging middle class that sought to differentiate itself from the impoverished, 'backward' masses. Such distinctions have been sonically articulated by the musical genres of pop Indonesia and Western pop on the one hand and dangdut and others on the other (see also Wallach 2002). Whereas pop Indonesia was a token of progress and modernity, dangdut music, its performers and fans are perceived of as disgusting and vulgar, and considered neither 'traditional' (that is, associated with indigenous performance traditions and high arts such as gamelan or tembang Sunda), nor truly 'modern' (mostly hinting at those expressions adapted from or originating in the West). This classed perspective of musical genres is obviously problematic and very much depends on which sources are consulted, and whose views are preferred. Dangdut fans have been written about, instead of writing themselves. Future studies of dangdut may problematize the now very dominant kampungan discourse, and would be a shift away from imposed class-related issues that 'outsiders' seek among dangdut fans. Looking at fan produced literature, videos and websites may teach us to see how dangdut fans represent themselves, among themselves, and possibly how they present themselves to non dangdut-fans by using a particular musical taste.

Sonically demarcating one's lifestyle is also well-illustrated by the popular Islamic nasyid songs as performed in Singapore, Malaysia, and Indonesia of the late 1990s. For non-Muslim listeners, nasyid is too religious to be popular due to the song's explicit Islamic messages, while many Muslims considered it too Westernized, and to some extent too modern, to be taken seriously as Islamic music. However, nasyid music has been extremely successful in offering a new young urban-based Muslim middle class a vehicle for articulating a new lifestyle, combining Islam and modernity (Kahn 2003; Sarkissian 2005; Barendregt 2006, 2011). More recently, Islamic talent shows such as the Malaysian Imam Muda or Festival Nasyid Indonesia have been instrumental in highlighting publicly spiritual lifestyles by offering role models and new celebrities selected through televized contests. Such contests have often been condemned as mere hedonism and an aping of Western consumerist culture. Nevertheless, there has been a long tradition of secular idols contests in this part of the world; shows which traditionally have succeeded in not only bringing artists and their audiences closer together, but which have also produced some of the most lucrative acts for the region's industries. Pereira (2011:2-3) refers as such to the talentime contests and the ways 1960 Singapore was full of entertainers deemed the this and that of 
Singapore, but through which also new and upcoming artists were discovered and new audiences attracted. But also the karaoke loving politicians and singing generals described by Kees van Dijk in his chapter fit well with this participatory pattern of much Southeast Asian music practices. $^{21}$

Youth culture is inherent to the world of fandom, audiences and lifestyle, although in Southeast Asia, as elsewhere, the category of youth is an ever changing one that merits further study. ${ }^{22}$ There are correspondences and yet differences between the rise of the apolitical remaja described by Siegel (1993) and late 1970s Solo and today's anak Gaul (Smith-Hefner 2007). The latter refers to teenagers who are familiar with the most recent trends in, e.g. music, film, internet and cellular phones, and who socialize easily with others, including the opposite sex, and who know the language of the youth, called bahasa gaul. Musical practices are shown to be part of larger formations of lifestyle, identity, and network in Lars Gjelstad's contribution to this book. In his ethnographic account of the cultural worlds in which some young urban Javanese consumers of pop music lived during the mid-1990s and early 200os, he shows the importance of popular music for the production of new forms of subjectivity, which in many ways break with deeply grounded Javanese conceptions of respect, etiquette, seniority and hierarchy. In the mid-199os, Gjelstad's initial fieldwork focused on the members of the Sugaly gang, named after the title of a song by Iwan Fals, Indonesia's most reputed folk singer and then an important critic of the New Order regime. ${ }^{23}$ Gjelstad's account vividly describes how the engagement of the Sugaly boys with music had an impact on their moral framing of rising involvement in a range of youth cultural practices, which besides the songs of Iwan Fals included the electronic sound of 'tripping' music, then becoming popular at Solo discothèques. Much in this new form of youth culture is inspired by the aesthetics of MTV-mediated video clips but, referring to Appadurai (1996), Gjelstad convincingly argues how such mass-mediated worlds offer 'scripts for possible lives' as well as new 'resources for experiments with self-making.' Whereas gaul is the latest signifier of such youth lifestyle, there are plenty of historical precedents, many of which similarly

${ }^{21}$ For recent accounts of such idols shows and the phenomena of Southeast Asian reality TV, see the works by Coutas (2006) on Indonesia, and Juliana Abdul Wahab (2010) on Malaysia.

22 For a recent overview of Indonesian youth studies, see Suzanne Naafs and Ben White (2012).

23 On Iwan Fals, see Mokoo (2003) and Lockard (1998:109). 
coincided with popular music expressions. ${ }^{24}$ Weintraub, in his chapter on 196os Melayu music, also hints at an emergent category of youth culture, but also the accompanying possibilities of intergenerational conflict. Using the song Djangan duduk di depan pintu (Don't sit in front of the door), a musical rendition of a father and daughter having words about the changing role of women, he shows the public transformation of both youth and gendered identities as they are 'discursively transcoded in popular song'.

In line with our interest in musical lifestyles, the contributors to this volume are particularly interested in cultural entrepreneurs who challenge social boundaries and hierarchies. We suppose that artists operating in the margins of dynamic urban centres often stood at the forefront of articulating modernity through new musical styles. This may be due to mixed ethnic origins, a particular social and cultural orientation, or the networks they are part of, enabling them draw upon heterogeneous cultural repertoires as a source of experimentation. The social groups from which they originate may involve Eurasians in the case of early twentieth century urban genres such as bangsawan, stamboel or kroncong (for accounts of such experiments, see S. Tan 1993; Cohen 2006; Keppy 2008), the young urban Western-inspired Muslims mentioned above or the city dwellers who, newly arrived to any of Southeast Asian's metropoles in the aftermath of a new socio-economic climate and ongoing urbanization, still stand with one foot in the village. A clear vocabulary to describe this category of people is absent. In terms of classical anthropology they approximate Turner's (1974) understanding of the 'liminal'. Regarding more recent literature, Rafael's (1995) 'phantomised identity' in his study of the Philippines is relevant to those who play, what De Certeau (2002:30) calls, the 'art of being in between'. They are intermediaries who appropriate popular music and embody the articulation of modernity as they straddle and, at times, challenge the social boundaries and hierarchies of class, race, religion, generation, gender and locality. New musical styles and associated lifestyles allow one to question existing social boundaries and to symbolically carve out new ones.

The making of popular music, then, involves the interplay among creative artists, an industry of some variety, and a socially differentiated

${ }^{24}$ Buni Yani, another PhD researcher working within our Leiden project, is writing about Remy Sylado and his iconoclast poetry (puisimembeling), named after an experimental rubric that in 1971/72 was first published in the very popular Aktuil journal he had helped launch, but was later also practised in many of his pop novels (see also Scherer 2006). 
audience, each of which has a stake in defining what is modern, what constitutes 'good taste, and what, finally, can be understood as the 'popular' (DeNora 200o; Bourdieu 1984). As the rigidities of established distinctions become difficult to sustain in eras of rapid social change, new forms of distinction are constantly explored. In the process, popular music transgresses class, gender and other social categories, while it is this act of transgression, through public behaviour, dress, language and sounds that enhances the appeal of popular music. The fact that many of these musical lifestyles are unstable helps to address the instabilities of social change and questioning old, while exploring, new social bonds (Miles 2000). However, one should be careful not to overstate music's role in challenging the social hierarchy, as Yampolsky's account of colonial radio also attests; popular music may cross boundaries, yes, but it seldom erases them. Similarly, Bettina David in her contribution on dangdut's attraction to Indonesians of all classes, explains how its live performances do not change or rework the symbolic order in itself, but rather exposes what she calls 'the semiotic basis of language and the symbolic'. Changes, then, are provoked through 'boundary transgressions' that may lead to public contestations (and she gives the examples of Inul Daratista dancing villagestyle dangdut on national television, or incorporating 'low-class' dangdut music into 'high art' genres such as wayang kulit). Nevertheless, once in a while popular musicians are involved in more than mere single transgressions when lines are all too clearly crossed, boundaries seem to fall apart and hence societal categories 'contaminated' and in need of reconfiguration. Hence, the interplay between modernity and tradition - one step forward, two back, but no matter what, difficult to stop.

\section{Changing Morals and the Fear of the Foreign and Female}

Modernity in popular music is a complex issue as it may both serve to detest or adopt what is considered to be foreign values and aesthetics. But even while considered deviant and not (yet) popular, it may well become a token of one's identity. The Sugaly boys studied by Gjelstad in his chapter labelled the cultural streams of contemporary youth as 'crazy' (aliran gila-gilaan). The fact that they select normative categories like crazy, stress and unruliness from dominant discourses in Java to comment upon their practices, demonstrates that they experience themselves as transgressing some cultural and normative boundaries. Sometimes it is religious norms that are transgressed, other times they run against current 
state policies or otherwise challenge the authorities to be. A good example of the latter is found in Adil Johan's contribution to this volume. His chapter tells a story of a continued policing of youth culture that has occurred in Malaysia since the late 196os. While the contestation in present day Malaysia centres on Islamic discourses of purity and protectionism, a similar discourse was present in the formation of the nation's National Culture Policy (NCP) in 1971. Johan argues that the NCP functioned as a hegemonic policy to counter a burgeoning cosmopolitan youth culture of Malaysia in the late 196os. Youth culture, expressed through music, dressing and lifestyle has consistently posed a threat to the state's articulation and imposition of a 'national' culture. A survey of articles and fan letters from the music magazine Bintang dan Lagu (Stars and Songs, 1966-67) reveals that young Malaysians were actively shaping locally unique musical practices based on trends from the West that were at odds with state-defined notions of national culture. Caught in between such contestations, however, were 'older' artists such as P. Ramlee (1971) who presented a reactionary paper on how to preserve and uplift - with much ambiguity - asli (authentic or indigenous) and traditional Malaysian music.

With the rise of the entertainment industry, as Stuart Hall (1981) argues, the popular can only be satisfactorily grasped by reference to Gramscian ideas, thus explaining how ruling classes exert domination over all others with a variety of apparently consensus-making means, including the use of media and entertainment to transmit its system of values. Popular culture is no longer simply those things that matter to masses of people who eagerly consume it; nor is it an ever expanding inventory of 'all things people do or have done'. Rather, it is about the relation between culture and questions of hegemony. Such transformations are at the heart of the (historical) study of popular culture, and during times of transformation one sees an active reworking of traditions. They appear to persist into modern times but more often gain new meaning. 'Popular culture [then] is neither, in a pure sense, the popular traditions of resistance to these processes; nor is it the forms which are superimposed on and over them. It is the ground on which the transformations are worked' (Hall 1981). Popular music has the potential to both connect and divide; a quality which has already been noticed by Thompson in his well known essay on 'rough music'. It can be utterly subversive, challenging state and clergy, but also horribly reactionary and used against those within the community 'crossing forbidden frontiers or mixing alien categories' (Thompson, as cited by Ferzacca 2012). 
Especially female performers, willingly or not, have often taken on a role of the 'modern girl', challenging conservatism, morality, religion and calling for change in attitudes and lifestyle, evoking admiration, discussion but also outright outrage. ${ }^{25}$

Several essays in this volume refer to the moral panic brought about by singing and dancing females. One of them, by Jan van der Putten, explains how cultural systems tend to be conservative in nature with social agents consolidating them in order to give a certain sense of stability to a community. In order to illustrate this, he explores the social context of ronggeng and joget practices in the first half of the twentieth century, thus illustrating what made it so incongruous with a cultural Malay identity that was being reconfigured and promoted through the budding popular press. ${ }^{26}$ Joget refers to the practice of itinerant groups of professional dance-women and musicians that is common throughout the Malay world and that has a long tradition. The dancing women perform on a make-shift stage where males are invited to participate for a certain fee. Whereas in previous times such incidents of social dance seem to have been restricted to special occasions, social dancing now became institutionalized in the emergence of modern entertainment parks and hence, was accessible to men of all ranks and race. New gained public visibility also meant that it was much more difficult for those who disapproved to look away. By looking at three cases of 'moral panic' in the period 1920s-1950s and launched from different interest groups within the Malay community, he shows how social dancing practices have been used to further various agendas, ranging from the religiously conservative to politically modern or even progressive. Whereas there may seem to have been little agency left for these dancing women themselves, Wallach and David, in their chapters, both describe how female dangdut performers in early twenty-first century Indonesia are keen on challenging the status quo, the person of Inul Daratista, a singer notorious for her trademark drill-dancing being a case in point. ${ }^{27}$ Wallach argues how eroticized performances of this sort, often accompanied by the drinking of alcoholic

25 This is not surprising as many authors have referred to the fact that the ushering of the media industry has generally been in favour of female artists. Both Van Zanten (this volume) and S. Williams (1998) have pointed out how Sundanese popular stages have increasingly become a female domain.

${ }^{26}$ For similar moral panics, see both Atkins (2001) and Jones (2001) on controversies sparked by and over the taxi girls of Shanghai.

27 For what was popularly phrased as 'Inulmania', see Faruk and Salam 2003; Weintraub 2010a, 2010b; Van Wichelen 2010; Sushartami 2012; and David and Wallach in this volume. 
beverages and other transgressive behaviour, historically have acted 'as instruments of (carnivalesque) male bonding across divisions of rank and status in many Indonesian groups'. Bettina David's contribution on the vulgar village variant of the same dangdut genre - in which songs are sung by scantily clad female singers and a predominantly young male audience dancing to 'sad' and sentimental songs on stage - argues how the discourse of dangdut's lyrics may well represent a popular and unofficial gender ideology. The female lyrical 'I' at the symbolical level seems to represent the passive, muted voice of Indonesian women; yet, at the semiotic level of rhythmic corporeal sensuality she is capable of seducing and controlling her male audience much in line with the power of traditional female singers (cf. Sutton 1984).

The fear of the female voice, be it secular or spiritual in character (see Barendregt 2006), has been an ongoing trope in many popular performance traditions that has recently been fuelled by bans on concerts by international artists such as Lady Gaga's in Jakarta and Erykah Badu performing in Kuala Lumpur. But moral panics about popular music have been about more than singing and dancing women. In a much quoted article, Philip Yampolsky (1989) explains the fate of the song Hatiyang luka (A wounded heart), a song that was much-copied, triggering spin-offs and one that successfully spilled over into other genres but was also fiercely condemned by then Indonesian Minister of Information, Harmoko. Despised for its defeatist lyrics, the Minister even called for a ban on this and similar 'weeping songs' ${ }^{28}$ In this volume, Baulch similarly relates how many critics complain that pop Melayu lyrics seem obsessed with sexual infidelity, its motivations and emotional effects, and see a kind of moaning as one of the genres' defining features. In both cases, lyrics are supposed to undermine the morale of what is framed to be 'the people', and hence in need of protection; a rhetorical device those in power have traditionally seemed to resort to when condemning things of their disliking (R. Williams 1984; Weintraub 2006). The literature similarly abounds with stories of those in charge being horrified by the 'alien performance culture' of foreign troops (Van der Putten, this volume), the predatory behaviour of kroncong- singing young males (Becker 1975), a young generation prone to miniskirts and long hair (Sen and Hill 2004; Farram 2007), or the supposed satanic behaviour of young metal aficionados in Malaysia (Yusof 2010). Recent attacks on popular music and its fans

${ }^{28}$ For similar reasons, another song, takdir by pop singer Desy Ratnasari, was banned by religious authorities (see Van Dijk, this volume). 
may similarly be seen as largely symptomatic of a larger fear of the foreign, with a resort to tradition as the much needed remedy for an unhealthy generation. In late 2011 about sixty young people were arrested by regular and shariah police for the supposed crime of being 'punk' during the staging of a charity concert in Banda Aceh. In a case much highlighted by the international media, those arrested were shown having their hair cut in what was supposed to be a traditional ceremony. 'The women's hair we'll cut in the fashion of a female police officer', a police spokesman was reported to have said: we'll change their disgusting clothes. We'll replace them with nice clothes. We'll give them toothbrushes, toothpaste, shampoo, sandals and prayer gear' (Global Post, 14December 2011). Moral condemnation seems to have given punk music another cause worth singing for!

The upsurge of a more orthodox, scripturalist and even radicalist interpretation of religion and its sometimes ambiguous relation to the performing arts is yet another persisting theme in the region's popular culture. Indonesian fundamentalist vigilante groups such as the Islamic Defenders Front (FPI) have been regularly reported to attack popular music venues (Weintraub 2010; Hoesterey and Clark 2012). In his contribution to this book, Van Dijk provides examples of similar hostile attacks by religious advocates for the Malaysian provinces of Kelantan and Terengganu, the Malaysian states that traditionally have been a stronghold of the Islamist PAS party. There are some noteworthy differences between Indonesia and Malaysia, though, as Van Dijk suggests. Compared to Indonesia there is no lively publishing press interested in books dealing with fatwa's on singing and dancing, but opposition to certain genres of music and certain types of dances and other art forms are nevertheless far greater in Malaysia and more institutionalized than in Indonesia. ${ }^{29}$ This is only one of many observations made possible by an area study approach, proving how the Southeast Asian region may turn out to be a fertile ground for analysing the triangle of the popular, modern and the social.

\section{Malayness and Other Nationalisms, Official and Unofficial in Character}

For centuries, (pen)insular Southeast Asia has been a fertile crossroads where cultural practices from elsewhere have merged in a multitude of

29 However, for an account of how Malaysian Islamist party PAS has been making ample use of rock musicians, see Müller (2012). 
new social forms and artistic genres linked to the modern, thus constituting a productive region for studying modernity in colonial and postcolonial settings (McVey 1998; Steedly 200o). Cities like Penang and Singapore were crucial trading nodes and. more recently, famous as centres of a modernist Islam, and the production of new literary, theatrical and musical genres. Referring to the late colonial period, Harper (1999) speaks of the region's urban centres as 'wellsprings of modernity'. Here, people from today's Malaysia, Singapore, Indonesia, and the Philippines mixed with migrants from India, China, the Middle East and Europe. It is these Southeast Asian cosmopolitan hubs that often acted as entrepôt between the larger world and its hinterlands and as a main interface through which modernity was communicated among the new national communities of postcolonial Southeast Asia. Although so far in this introduction we have used the term Southeast Asia to refer to our main unit of analysis, we are well aware of the limitations.

Within the Leiden project some of us do work on popular music genres and artists in the Philippines or Thailand, and some of our forthcoming studies will focus on more than a single country, intentionally promoting intraregional comparison. ${ }^{30}$ In all fairness we should say that with some exceptions most of the essays here are still nation centred, with many of them drawing heavily on Indonesian materials (but then half of the Southeast Asian population is Indonesian); Singapore and Malaysia being the two other countries under study here. Whereas today it is utterly amazing that only a few genres and artists successfully manage to address the region as a whole, historically it has been very difficult to separate these three markets. Only from the late 196os onwards did these countries develop singular domestic markets and each an own infrastructure for recording, distribution and management.

It would be apt to say that our volume's overall focus is on what Yampolsky (during one of our workshops) framed as the 'IMS region' (Indonesia-Malaysia-Singapore, or alternatively, Indies - Malaya - Straits Settlements). Traditionally this area has been designated by many as 'the Malay world', and hence its use in this volume's title. Along with Barnard

30 Popular music studies of the region are desperately in need of thorough decentring, and again a history of border crossing agents, technologies and genres may be an important step in doing so; but scholars should also dare to step away from the traditional recording capitals and into the regional hinterlands (see next section) as well as focus on some of the more supraregional genres. Not coincidentally, genres that have moved beyond the nation's territories are often religious, regional/pan Asian or ethnic in character - three other ways of anchoring identity in a postcolonial world. 
and Maier (2004) we realize the pitfalls of using the term, which refers to a 'confusing variety of configurations of human beings, locations, languages, customs, states and objects', and also realize that its use here may not be sufficient in covering all cases offered in this volume (Javanese youth culture, Chinese Malay pop yeh yeh). We use the term Malay or better 'Melayu' here primarily as a discursive category. In his chapter, Weintraub argues how, historically, 'Melayu' must be understood as a hybrid, flexible, and constantly evolving stage upon which people constructed their cultural identity and history in the region. The term, as he shows, predates colonial times and has been used to refer to both an ethnic group (suku Melayu) that has traditionally resided around the Melaka Straits and Riau, but also a larger 'racialized group' (rumpun Melayu) that populates the modern nation states of Indonesia, Malaysia, Singapore, Brunei Darussalam, and (southern) Thailand in Southeast Asia. ${ }^{31}$ The use of a wider culture area such as the Malay World also advocated here is also very much driven by the need to include into one single analytical framework popular music expressions produced by what are now inhabitants of various nation states. This is especially urgent as we would like to address the often seemingly inescapable lure of nationalism for both inhabitants and students of the region. It is an important, yet not all encompassing, factor when it comes to popular music. However, and in spite of our stress on the border crossing and often fluid qualities of much popular music, the very same popular music that connects people across borders may serve as an outspoken means to strengthen national markets. In fact, Anderson's (1991) is a classic study of how national audiences were created by the mass entertainment industry. But Yampolsky, too, builds upon such an argument as he, elsewhere in this volume, states that radio and records adapted to fragmentation by trying to serve all of the principal ethnic groups. But [yet] the strongest impulse of mass media is to maximize the audience, to market to the mass, and since no ethnically or regionally delimited music could serve as a mass Indonesian music, it was necessary to adopt symbolic forms free of such linkage [...]. Popular music in foreign musical idioms and instrumentation and sung either in a foreign language or in Indonesian was one such form'.

Hence, a number of the essays in this book are concerned with the formation and dynamics of national popular genres that emerged in the

31 For more on the historical emergence of the concept of Melayu, see Andaya (2001), Milner (2008) and, in relation to current heritage policies, works such as that of Worden (2001). 
aftermath of the newly gained independence of the 1950/6os. In terms of national pop, for example, scholars of Indonesia have generally followed the distinction made by the music industry centred in Jakarta, which itself distinguishes between either 'national' or 'regional' genres of music. Whereas the latter will be dealt with in the next section, national genres include localized forms of rock, hardcore, rap, country, jazz, disco, house, Hawaiian, and pop Indonesia, but also kroncong and dangdut, that generally feature lyrics in Indonesian (though sometimes in English) and are marketed primarily in urban regions throughout the archipelago (Barendregt and Van Zanten 2002). Again, the distinction is for the most part industry-driven, and the two levels have at times proven hard to separate from each other, with artists, producers and audiences regularly crossing over in each other's domain. Additionally, Wallach (referring to a 1999 essay by musicologist Thomas Turino) argues that national musics themselves can regularly be considered as hybrid forms that aim to articulate 'local' musical elements (indexing community and cultural uniqueness) with Western elements that index the modernity to which all nations seem to aspire. This 'strategic hybridization' results not only in national cultural forms that mediate between the local and the global, but also reconcile the 'dual yearnings of the citizenry for the cosmopolitan modern on the one hand and the preservation of cultural distinctiveness on the other' (Wallach, this volume). The ongoing dialectic of local, regional and the global, then, importantly feeds into what is popularized as being modern in a certain place and at a certain time, as most essays in this book so vividly capture.

As an example, Weintraub's chapter discusses the hybridization of American popular music and Melayu music in Pop Melayu, a genre of American-influenced Melayu music that enjoyed popularity in Indonesia as well as Malaysia during the 1960s. The historical development of that genre can be traced to the early 196os, and straddles Sukarno's Old Order and Suharto's New Order. Despite the Sukarno regime's efforts to ban American films and music from entering Indonesia, hundreds of illegal student-run radio stations in Jakarta broadcast prohibited recordings of American popular music. Pop Melayu as it was reinvigorated by popular artists combined some of the most progressive (American pop) with some of the most conservative (Melayu) music. Composers incorporated musical instruments, rhythms, and verse structures that signalled a link to 'Melayu' identity, as the concept was at the time discursively practiced in Indonesia. Melayu, as many knew, stood for tradition, a connection to forge with fellow Malays and Muslims, and for something larger than 
promised by the contemporary Indonesian nation and its neighbour Malaysia; that 'colonial construct' which, much to the disdain of Sukarno in the 196os, was created by the English colonizers and which increasingly started to usurp the notion of Melayu itself. The readymade though fluid notion of Melayuness then may very well have served as a safe haven in times of uncertainty (Indonesia was a republic now, but a far from stable one) and out of sheer discontent with the shape official nationalism was increasingly taking. The mass appeal of Melayuness can also help explain its periodic resurgence within the entertainment industry, even more so when, after 1965, (exponents of) pop Indonesia soon became very close with the Suharto administration. Baulch's chapter thus refers to the Indonesian military's use of state-prohibited Western style pop and rock music through so-called 'soldier stages' in order to interest people in its new regime of governance, beginning with the mass killings and arrests of $1965^{-6}$.

Popular songs may consequently serve to harness the interest of leaders, politicians or others affiliated to the government apparatus. At the turn of the new century, Filipino president Arroyo and the current Indonesian president Susilo Bambang Yudyoyono are good examples of singing politicians, but there is a wider tradition of (retired) generals and other power holders performing in public places in several of the countries under study here. As Kees van Dijk argues, politicians may sing for fun or to try to increase their popularity, but their performances create the impression that the singing of popular songs also has something to do with power, with high political and social status. Singing promotes one's career but can also gain one some extra votes; hence, performances tend to increase whenever elections are due (see also Chua 2007). ${ }^{32}$ But there is a different face to singing songs to highlight patriotic campaigns, as the very same songs may be sung by demonstrators telling the elite that 'they have lost all sense of patriotism and social justice, that they had become selfish, greedy and oppressive' (Van Dijk, this volume). ${ }^{33}$ Dangdut, in one

32 That this is by no means a recent development was also pointed out by one of our reviewers, who referred in this respect to Wet earth and warm people (1971), a Canadian film directed by Michael Rubbo which shows General Hoegeng singing Hawaiian songs on national Indonesian television, a fact also mentioned in the contribution by Van Dijk here.

33 Van Dijk (2003) describes how one striking feature of the 1998 student demonstrations in Indonesia was its choice of patriotic symbols as both the patriotic lyrics of the struggle songs and the long marches in which they were sung are signs of the success of Indonesia's New Order indoctrination. Tyson (2011:23) provides us with another example of the ambiguity of patriotic songs in describing Harry Roesli's rendering of the song Satu nusa satu bangsa (One homeland, one nation) during the 1995 golden anniversary of 
sense heir to the pop Melayu tradition, may similarly serve as such a counterpoint. Dangdut's everyday grassroots, or what Michael Billig (1995) refers to as 'banal nationalism' offers a vision with roots in the early Indonesian nationalist movement; an egalitarian ethos that appealed to many that have been left out of the otherwise very successful New Order chronicle of modernization, progress and development. Jeremy Wallach argues that dangdut's ideological positioning as a distinctively national music 'close to the people' evokes an inclusive social vision that constitutes a populist alternative to both the Suharto era's hegemonic ideology of 'development' and the exclusivist, moralistic rhetoric that was propagated by Indonesian radical Islamists from the early zooos onwards.

In neighbouring Malaysia music has likewise served nationalist purposes, here too both official and unofficial in character. In contrast to neighbouring Indonesia, there is in the absence of a true war of liberation no real tradition of songs of struggle, but Malaysia has fared much better in creating a national genre that has been both outspokenly traditional yet able to fill modern stages and address modern demands: Irama Malaysia (S. Tan 2005). Hamzah and Shamsul discussed during one of our workshops the Malaysian state's effort at 'political marketing' or 'national branding' of songs. Popular music in a Malaysian context has traditionally been marketed along ethnic lines: Malay music for Malays, Chinese for Chinese, Tamil for Tamil Indians. Except for English and Hindi songs the only songs to reach across all ethnic groups are those created by the state in order to promote its various programmes and national slogans because such songs are aired on all public radio and television stations in all the different language media, day in and day out, sometimes for months on end. These songs ${ }^{34}$ are also sung at school assemblies and government official functions throughout the country. 'Young or old can easily hum any of the state songs by heart, albeit, depending on which generation of the country the individual belongs to [...]. They are an inevitable part of everyone's life and escaping them is impossible. Acknowledging full well that these state songs are "authority-defined social realities" in Malaysia,

Indonesia's independence. See also Lily Kong's (1995) analysis of the governmental 'Sing Singapore' programme and the form of cultural resistance this has triggered locally. Finally, Mitchell (2011) gives a Thai example looking at some of the satirical songs and lukthung that have been used by both red-shirt protestors (the UDD) and their yellowshirt opponents (the PAD) in the country's ongoing political struggle.

34 These songs include lagu patriotik (patriotic songs), lagu tradisional negeri-negeri (states' traditional songs) and lagu rakyat (public people's songs), a categorization originally devised by the Ministry of Information, Communication and Culture. 
nonetheless, due to its frequent repetition they have created particular brand equity for the country' (Hamzah and Shamsul 2011).' In other words, songs such as Malaysia berjaya (Malaysia has succeeded), Setia (Loyal) or, more recently, OneMalaysia may not be popular songs in the strict sense of the word, but become popular as a result of being repeated hundreds of times over an extended period of time, and sung publicly by fans and nonfans alike. Examples of the latter are provided in a study by Koh (2008) on the Chinese Malaysian student Wee Meng Chee, who under his alias Name Wee published a couple of rap songs on YouTube. His 2007 release Negarakuku (a pun on the title of the national anthem, a sample of which is used in the song) stirred a huge controversy in his home country as its lyrics satirized the corruption and inefficiency of the Malaysian police and government officers, and especially the unequal citizenship of Chinese Malays. For months the song polarized Malaysian society as opposition parties and civil society groups challenged the government's interpretation of the song and its significance.

Popular music, then, frequently acts as a tool to sanction new modern and nationalist culture, but at the same time its values are challenged through the very same popular songs that serve as a vehicle for yet other, alternative forms of belonging. The hybridization of the local unique and the cosmopolitan modern seldom passes uncontested. Nor is the role of Southeast Asian recording capitals as the main interface of modernity entirely unchallenged, although large parts of the industry today remain as focused on Jakarta, Kuala Lumpur or Singapore as they were back in the 1930s. These centres are not on their own and each of them in its sheer creativity depends on yet other satellite hubs of creativity, which flourish due a huge student population (Jakarta vs. Bandung and Yogya), the presence of a foreign military base (Manila vs. 196os Olongapo, where a military base was located) or thanks to being better situated in the international businesses network (the Singapore industry as opposed to musicians signed from both Malaysia and Indonesia). Accordingly, there is a need for remapping the topography of Southeast Asian popular music in more detail and with far more attention for the supraregional as well as pan-Asian popular forms that currently flood the region, ${ }^{35}$ but also paying due attention to those smaller local industries that have developed away from the centre.

35 For studies of Pan-Asianism in pop, see the analysis of Dick Lee by Wee (1996) and Mitchell (2004). For the more recent fashion of Japanese pop and especially the huge popularity of Korean Wave in Southeast Asia, see Shim (2006), Chua and Iwabuchi (2008) and especially Siriyuvasak and Hyunjoon (2007). Another study that has not yet been done but 


\section{The Modern Ethnic}

Novel, 'modern' technologies in the early twentieth century, such as records and radio, served to shape and unite new audiences and helped to create some of the most vivid national genres in the countries under study here. However, throughout the twentieth century these technologies have also been instrumental in forging other forms of belonging that were often diametrically opposed to new-born nationalist sentiment.

Elsewhere in this volume, Weintraub remarks how one productive effect of President Soekarno's opposition to Western popular music in the late 1950s has been to encourage producers, composers, musicians, and singers to mix regional songs with Western musical elements (see also Piper and Jabo 1987; Barendregt 2002). Similarly, when during the late 1970s much of the nationalist magic lost (again) its appeal such resentment had a sonic dimension. This was a time of rapid urbanization and homogenization with peoples of different ethnic origins mixing in Southeast Asian capitals such as Jakarta or Kuala Lumpur and the related need to mark those different identities. National policymakers fearing political risks tried to quell ethnic sentiment by subjecting it to various nationalist tactics, such as the folklorization of the regional arts in Indonesia, or in Malaysia by propagating ethno-nationalist policies that subdued regionalist identities. But it is especially in this era that counter-modernist readings prevail, ${ }^{36}$ which romanticize village life, 'that imagined site of ignorance, stasis, and resistance to national modernity' (Wallach, this volume). It is under these circumstances that participants have been prone to articulating 'the ethnic modern', by connecting residual musical traditions to the latest urban trends and technologies. ${ }^{37}$

which is particularly urgent in the context of Indonesia is the status of Chinese language popular music. For an industry that is largely Chinese owned there has been remarkable little marketing of Chinese hit genres, nor any indication of genuine localized versions of genres that traditionally have been popular among the Chinese Diaspora, such as Canto-pop.

36 Obviously for those studying Indonesia, similar decentralizing tendencies took place in the aftermath of the Reformasi period and its subsequent call for regional autonomy (otonomi daerah), triggering new intercultural processes and a return to the local as a response to the New Order's centre-periphery model (see also Weintraub 2010:217).

37 This response of Indonesian traditional musicians inserting their musics with more popular sounds, genres or technologies from elsewhere may well have been triggered by the very same forces that in the Suharto administration sought and still seek to teach villagers not to want their traditional music (see for a more exhaustive comment, Yampolsky 2001). 
Facilitating the regional pop fashion that saw the rise in the early 1980 , were new cheap grassroots media technologies allowing musical entrepreneurs to re-engage localized forms of identity and offering a platform for the ethnic and traditional genres those industries previously ignored. Manuel (1993) documents how the advent of cassette technology at this time results in decentralization and the fragmentation of decades of state and multinational monopolies. Compared to old, centralist and relatively expensive media like radio, cinema and gramophone, these new micro media practices facilitate grassroots musical initiatives, creating niche markets for genres hitherto disregarded by the industry. In Indonesia, the 1970 s and 1980 s ushered in a golden age for regional pop; various regional genres like pop Minang, pop Batak or Pop Sunda became so popular, that for years regional stars outstripped national ones in fame.

A regional popular music is targeted at consumers who are the residents of a specific region, or the members of specific ethnic groups, rather than at Indonesians in general (Yampolsky 1989:12-13). Lyrics tend to be in 'local' or 'ethnic' languages and dialects such as, for instance, Sundanese or Ambon Malay. But how is the ethnic made to sound? ${ }^{38}$ In his contribution to this book, Wim van Zanten regrets that too many popular music studies, especially in the field of cultural studies, have focused purely on political and sociological aspects, to the exclusion of musical structures and actual sounds. ${ }^{39}$ Why not focus on popular music as being music? Van Zanten embarks on his mission showing how musical features in various popular musics of West Java mean that the music may be called 'Sundanese', named after the majority ethnic group populating that particular region. Analysing several versions of two well-known Sundanese songs and how these songs are variously interpreted over time, Van Zanten shows that whereas in the 196os-1970s the style of performing included many Western aspects, (including high final notes, trumpets and organs, elements from blues, Hawaiian guitars and rock-n-roll), later recordings started to incorporate the archetypical Sundanese suling flute, even while sometimes played on electronic instruments. The persistence of the Sundanese tone systems pélog and sorog in popular song traditions have generally been regarded as one of the important criteria for deciding

38 For other analyses of regional pop, see Hatch (1985) and Sutton (2003); and for particular genres, amongst others, Barendregt (2002), Suryadi (2003) and Fraser (2011) on pop Minang; Hodges (2006) on pop Batak; S. Williams (1990) and Jurriëns (2004) on pop Sunda, and Arps (2009) on popular music for the Banyuwangi area of Eastern Java.

39 See Moore (2006) for a similar critique. 
whether a song qualifies as pop Sunda and, as Van Zanten argues, their being played on electronic instruments should not make a difference. The use of keyboard synthesizers may have a standardizing effect on the pitch of the popular songs; nevertheless, 'the musicians are still able to let their audiences see the world in an enchanted form, musically coloured "Sundanese" by the use of Sundanese tone systems, mostly 8 and 16-beat musical phrases, singing ornaments, musical patterns, and the melancholic sound of the suling' (Van Zanten, this volume).

Regional pop genres such as pop Sunda, pop Batak or pop Minang seem to have been highly successful in generating new bonds among migrants of particular regions now living in the larger Southeast Asian cities, partly through dissemination of these new regional genres by distribution networks that often extended far beyond the nation's borders. Due to the creation of an often overarching regional style, emblematic use of ethnic or regional traditions and language standardization, it also led both city dwellers and those in regions to identify with a larger 'traditional' community that undercut national loyalties. In sum, in this (but also later) period, modernity is seemingly articulated away from nationalist interpretations through recourse to the familiar, an undercurrent of traditional, often ethnic affiliation, that had been publicly elided. Ironically, it should be noted that the resulting regionally produced pop music was initially produced in the nations' capital where, at the time, the music industry was based, far from the region that inspired it. From here, recording companies mushroomed in provincial towns like Medan, Padang, Bandung and Makassar in Indonesia. Far less is known about the cassette recording industry's impact in Malaysia, but we suspect that processes of regionalization and critiques of modernity must have similarly dominated. We do know that a regional pop industry has similarly existed in places such as Sarawak and Sabah (Lockard 1998:225) but it was never as successful as its Indonesian equivalents. Questions thus remain for Malaysia and also neighbouring countries regarding which genres were taken up in redefining ethnic and traditional genres and which, in the course of time, succeeded or failed to be promoted as new popular forms? To what extent was regional pop music also invented in these countries and directed at a rural audience or addressed the needs and identity confusion felt by migrants to cities? These are all questions for future research. For certain is that in the Malaysian context, the renewed interest for ethnic and traditional genres seems to have focused primarily on Malay musical traditions, generally marginalizing genres popular among other ethnic groups, especially those of the already marginalized forest 
dwelling groups. ${ }^{40}$ However, also here tradition has come back with a vengeance.

In the final contribution to this book, Tan Sooi Beng describes how 'world music'- a marketing term that first emerged in the 1980 - has triggered responses among local Malay musicians who have been keen to mix their own Malay, Chinese, and Indian musical traditions with African and Latin Rhythms. As elsewhere world music on stage and record has foregrounded the tension between cultural homogenization and heterogenization, the local and the global, the modern and the traditional. By focusing on the musical collaboration of the forest dwelling Orang Asli community with urban musicians, as well as the Sarawak Rainforest World Music Festival (RWMF), Tan illustrates that world music 'has had a positive effect of validating musicians and musics of the indigenous communities in Malaysia who have been marginalized and are trying to survive under precarious conditions' (S. Tan, this volume). While Malaysian mainstream media have largely tended to ignore these modern ethnic songs, as they are deemed critical of government and do not conform with the non-controversial musical styles promoted by the Malaysian entertainment industry, world music is also seen as a way to remove the image of backwardness among Orang Asli populations. By presenting the songs in a modern setting, a younger generation of Orang Asli has been inspired to learn these songs. Using modern instruments such as the guitar and keyboard and the world music idiom helps the younger generation to engage with modernity, while not losing pride of one's tradition. Tan's piece nevertheless show the ambiguous character of modern ethnic songs, which mostly remain a prerequisite of urban migrants, and detached from long house and ritual context easily become a medium for self-orientalization. World music, then, has become one of the latest arenas in which to articulate Southeast Asian tradition with modern sounds, ideas and lifestyles.

\section{Remembering the Twentieth Century, as we Listen to it...}

At the turn of the twenty-first century, Southeast Asian pop music is a world calling out loud to be explored by music lovers and academics alike.

\footnotetext{
40 Although lately, under the banner of musical heritage, much has been done to revive an interest in both traditional and popular performing arts of Malaysia. For examples, see the work by Tan.
} 
Not only has Southeast Asian popular music proven to be an auditory component of various forms of new belongings, ranging from new religious, pan-Asian or ethnic modern identities, it increasingly succeeds in interesting a world out there in all things related to Southeast Asia. Outside the Malay world, dangdut has achieved some success as a 'world music' genre among middle class listeners in Europe, North America and especially Japan. Korean and Japanese agencies are keen on recruiting their latest talents from the region, still following pretty much the capitalist rationale of Western entrepreneurs before them; you need software (the singer) to sell the hardware (East Asian audio equipment). And Asian diva's such as Siti Nurhaliza or Islamic boy band Raihan have become used to performing in other languages than their own and are often seen abroad. The pioneering use of novel technology by those in otherwise sometimes marginal positions persists to be an important drive behind many popular productions nowadays. As we have seen, it has provided both the young, minorities and forest dwellers with means to popularize their own songs and use marketing strategies similar to those of a still thriving but ever changing entertainment industry. Importantly, new digital technologies, tools and platforms have also facilitated an interest in pop history itself; in the sights and sounds of twentieth century performers and the songs they have been producing.

Today, the internet provides music lovers of and in the region with the means to discuss, share and play their music. The Net is home to countless fan sites, detailing the minutiae and whereabouts of their idols, it accommodates home pages of artists themselves who, often without intervention from conglomerates, are able to launch their latest hit songs and related merchandise. It also provides sound archaeologists, sonic detectives, discographers amateur, and academics alike with the means to seriously undertake and update their research on what the twentieth century may have sounded like, and what it tells us about the history of a particular people and their place in the world. ${ }^{41}$

One only has to open up YouTube to find countless hit songs, film tracks or evergreens performed by Southeast Asian artists, with user comments vividly describing what the song has meant to its listeners to understand: there is something particular about music that activates the human memory. It may explain the plethora of re-releases of 1960 and $1970 \mathrm{~s}$ records in recent years, the retro longing of musical acts such as White

\footnotetext{
${ }^{41}$ In fact topic of our project's next volume Participatory Pop Practices, which is due to appear in late 2014.
} 
Shoes and the Couples Company, Amy Mastura or Dick Lee, but also the ongoing popularity of cover bands and reunion concerts that hail the musical achievements of the region. Not only is much music well remembered, music clearly is an indispensable means in retrieving memory. The idea of a record reiterating the same content each time it plays is subconsciously transposed onto the experience attached to hearing the music. 'People's expectations to feel the same response each time the record is played, stems from a craving to relive the past as it was - as if the past was a record' (Van Dijck 2006). The twentieth century has been extremely successful in producing such 'sound souvenirs' 42 and it is through them that we sometimes gain surprisingly new insights in the coming of modernity and how it has been situated within localized and time-bound debates. It is time that these musical memories receive the academic interest they deserve and we are just embarking on such an enterprise. Ours is a project that is situated in the 'borderlands' of anthropology, history, cultural studies and musicology with data drawn from a range of sources. Our aim is to map the infrastructure of the region's music industry, to help identify popular artists and genres, and to build biographies of key artists and cultural brokers, as well as identify audiences and lifestyles; and yes, even shifting social categories. If this book somehow contributes to such interests and invites others to follow, our mission has been accomplished...

\section{References}

Abdul Wahab, J. 'Malaysian reality TV: Between myth and reality', Jurnal Komunikasi Malaysian Journal of Communication 26-2:17-32, 2010.

Adorno, T.W., R.D. Leppert and S.H. Gillespie. Essays on music. Berkeley, CA: University of California Press, 2002.

Andaya, L. 'The search for the "origins" of Melayu', Journal of Southeast Asian Studies 32-3:315-30, 2001.

Anderson, B.R.O'G. Imagined communities: Reflections on the origin and spread of nationalism. Revised edition. London: Verso, 1991.

Appadurai, A. Modernity at large: Cultural dimensions of globalization. Minneapolis, MI: University of Minnesota Press, 1996.

Arps, B. 'Osing kids and the banners of Blambangan: Ethnolinguistic identity and the regional past as ambient themes in an East Javanese town', Wacana. Jurnal Ilmu Pengetahuan Budaya 11-1:1-38, 2009.

Atkins, E.T. Blue Nippon: Authenticating jazz in Japan. Durham: Duke University Press, 2001.

Barber, K. Readings in African popular culture. Bloomington, IN: International African Institute/Indiana University Press, 1997.

42 The term is taken from a collection of essays edited by Bijsterveld and Van Dijck (2009) which deals with similar and related issues of the remembering of and by music. 
Barendregt, B. "The sound of "longing for home". Redefining a sense of community through Minang popular music,' Bijdragen tot de Taal-, Land- en Volkenkunde 158-3:411-50, 2002.

- . The art of no-seduction: Muslim boy band music in Southeast Asia and the fear of the female voice', IIAS Newsletter 40 (March 2006):10, 2006.

— . 'Pop, politics and piety: Nasyid boy band music in muslim Southeast Asia, in A.N. Weintraub (ed.), Islam and popular culture in Indonesia and Malaysia, pp. 235-56. London: Routledge, 2011.

- 'Sonic discourses on muslim Malay modernity: The Arqam sound', Contemporary Islam (October 2012) 6-3:315-340, 2012.

Barendregt, B. and W. van Zanten. 'Popular music in Indonesia: Mass-mediated fusion, Indie and Islamic music since 1998', Yearbook for Traditional Music 34:67-113, 2002.

Barnard, T.P. 'Sedih sampai buta: Blindness, modernity and tradition in Malay films of the 1950s and 196os', Bijdragen tot de Taal-, Land- en Volkenkunde 161-4:433-53, 2005.

- 'Decolonization and the nation in Malay film, 1955-1965', South East Asia Research 17-1:65-86, 2009.

Barnard, T.P. and H.M.J. Maier. 'Melayu, Malay, Maleis: Journeys through the identity of a collection', in: T.P. Barnard (ed.), Contesting Malayness: Malay identity across boundaries, pp. ix-xiii. Singapore: Singapore University Press, 2004.

Baulch, E. Making scenes: Reggae, punk, and death metal in 19gos Bali. Durham, NC: Duke University Press, 2007.

—_. 'Music for the pria dewasa: Changes and continuities in class and pop music genres', Journal of Indonesian Social Sciences and Humanities 3:99-130, 2010.

Baumgärtel, T. 'The piracy generation: Media piracy and independent film in Southeast Asia', in: M.A. Ingawanij and B. McKay (eds), Glimpses of freedom: Independent cinema in Southeast Asia, pp. 195-207. Ithaca, NY: Southeast Asia Program, Cornell University, 2012.

Becker, J. 'Kroncong, Indonesian popular music', Asian Music 1:14-19, 1975.

Billig, M. Banal nationalism. London: Sage, 1995.

Bourdieu, P. Distinction: A social critique of the judgement of taste. Cambridge, MA: Harvard University Press, 1984.

Burke, P. 'The discovery of popular culture', in: R. Samuel (ed.). People's history and socialist theory, pp. 216-26. London: Routledge and Kegan Paul, 1981.

- What is cultural history? Cambridge: Polity Press, 2004.

Bijsterveld, K. and J. Van Dijck. Sound souvenirs: Audio technologies, memory and cultural practices. Amsterdam: Amsterdam University Press, 2009.

Certeau, M. de. The practice of everyday life. Berkeley, CA: University of California Press, 2002.

Chaney, D.C. Lifestyles. Key ideas. London: Routledge, 1996.

Chen, K.-H. and B.H. Chua. The inter-Asia cultural studies reader. London: Routledge, 2007.

Chua, B.H. (ed). Elections as popular culture in Asia. London: Routledge, 2007.

Chua, B.H. and K. Iwabuchi. East Asian pop culture: Analysing the Korean wave. Hong Kong: Hong Kong University Press, 2008.

Chun, A.J.U.L. and N. Rossiter. 'Introduction: Cultural imaginaries, musical communities, reflexive practices', in A. Chun, N. Rossiter and B. Shoesmith (eds), Refashioning pop music in Asia: Cosmopolitan flows, political tempos, and aesthetic industries, pp. 1-14. New York, NY: Routledge Curzon, 2004.

Cohen, M.I. The Komedie Stamboel: Popular theater in colonial Indonesia, 1891-1903. Athens, OH: Ohio University Press, 2006.

_. Performing otherness: Java and Bali on international stages, 1905-1952. New York: Palgrave Macmillan, 2011.

Coutas, P. 'Fame, fortune, fantasi: Indonesian idol and the new celebrity', Asian Journal of Communication 16-4: 371-92, 2006.

Dairianathan, E. 'Vedic metal and the south Indian community in Singapore: Problems and prospects of identity', Inter-Asia Cultural Studies 10-4:585-608, 2009. 
—. 'Soundscapes in vedic metal: A perspective from Singapore', Perfect Beat 12-2:167-89, 2012.

David, B. 'Intimate neighbors: Bollywood, dangdut music, and globalizing modernities in Indonesia', in: S. Gopal and S. Moorti (eds), Global Bollywood: Travels of Hindi song and dance, pp. 179-99. Minneapolis, MI: University of Minnesota Press, 2008.

DeNora, T. Beethoven and the construction of genius: Musical politics in Vienna, 1792-1803. Berkeley, CA: University of California Press, 1997.

—. Music in everyday life. Cambridge: Cambridge University Press, 2000.

- 'Musical practice and social structure: The sociology of music and its toolkit', in E. Clark and N. Cook (eds), Empirical musicology, pp. 35-56. Oxford: Oxford University Press, 2004.

Dijck, J. van. 'Record and hold: Popular music between personal and collective memory', Critical Studies in Media Communication 23-5:357-74, 2006.

Dijk, K. van. 'The magnetism of songs', Bijdragen tot de Taal-, Land- en Volkenkunde 159-1:31-64, 2003.

Eisenstadt, S.N. 'Multiple modernities', Daedalus, 129-1:1-29, 2000.

Farram, S. 'Wage war against Beatle music!: Censorship and music in Soekarno's Indonesia', Review of Indonesian and Malaysian Affairs 41-2:247-77, 2007.

Farrell, G. Indian music and the West. Oxford: Oxford University Press, 1999.

Faruk, H.T. and A. Salam, Hanya Inul. Baciro Baru, Yogyakarta: Pustaka Marwa, 2003.

Ferzacca, S. 'Deep sound, country feeling: Kroncong music in a Javanese neighbourhood', Asia Research Institute: Singapore. [Working Paper 180.] 2012.

Fraser, J. 'Pop song as custom: Weddings, ethnicity, and entrepreneurs in West Sumatra', Ethnomusicology 55-2:200-28, 2011.

Frederick, W.H. 'Rhoma Irama and the dangdut style: Aspects of contemporary Indonesian popular culture', Indonesia 34:102-30, 1982.

Gaonkar, D.P. 'On alternative modernities', Public Culture, 11-1:1-18, 1999.

Geertz, H. Indonesian cultures and communities. New Haven: HRAF Press, 1963.

Geschiere, P., B. Meyer and P. Pels. Readings in modernity in Africa. London: International African Institute in association with Indiana University Press, James Currey, Unisa Press, 2008.

Gronow, P. 'The record industry comes to the orient', Ethnomusicology 2:251-84, 1981.

Grossberg, L. We gotta get out of this place: Popular conservatism and postmodern culture. New York: Routledge, 1992.

Hall, S. 'Cultural studies: Two paradigms,' Media, Culture and Society 2-1:57-72, 1980.

—. 'Notes on deconstructing "the popular"', in: Samuel, R. (ed.), People's history and socialist theory, pp. 227-41. London: Routledge and Paul Kegan, 1981.

- . 'Popular culture and the state', in T. Bennett, C. Mercer and J. Woollacott (eds), Popular culture and social relations, pp. 22-49. Milton Keynes: Open University, 1986.

- 'On Postmodernism and articulation: An interview with Stuart Hall, edited by Lawrence Grossberg,' in: D. Morley and Kuan-Hsing Chen (eds), Stuart Hall: Critical dialogues in cultural studies, pp. 131-150. London: Routledge, 1996.

Hamm, C. 'Popular music and historiography', Popular Music History 1-1:9-14, 2004.

Hamzah, S. and A.B. Shamsul. 'Songs of the state: Advertising and branding national interest in Malaysia'. Paper presented at the international conference 'The Beat Goes On: Popular Music in Twentieth Century Southeast Asia', organized by KITLV, Jakarta, 10-11 January, 2011.

Hanan, D. and B. Koesasi. 'Betawi moderen: Songs and films of Benyamin S from Jakarta in the 1970 - further dimensions of Indonesian popular culture', Indonesia $91: 15^{-76}$, 2011.

Harding, J. and A. Sarji. P. Ramlee: The bright star. Subang Jaya, Selangor: Pelanduk, 2002.

Harper, T.N. The end of Empire and the making of Malaya. Cambridge: Cambridge University Press, 1999. 
Hatch, M. 'Popular music in Indonesia', in: D. Horn (ed.), Popular music perspectives 2: Papers from the Second International Conference on Popular Music Studies, Reggio Emilia, September 19-24, 1983, pp. 210-27. Göteborg, Sweden: IASPM, 1985.

Hefner, R.W. 'Multiple modernities: Christianity, Islam and Hinduism in a globalizing age', Annual Review of Anthropology 27:83-104, 1998.

Heryanto, A. Popular culture in Indonesia: Fluid identities in post-authoritarian politics. London: Routledge, 2008.

Hobsbawm, E.J. The jazz scene. London: MacGibbon and Kee, 1959.

Hodges, W.R. 'Referencing, reframing, and (re)presenting grief through pop laments in Toba Batak (North Sumatra, Indonesia)', http://repository.usu.ac.id/handle/123456789/15256 (last accessed August 2012), 2006.

Hoesterey, J.B. and M. Clark. 'Film islami: Gender, piety and pop culture in post-authoritarian Indonesia, Asian Studies Review: Journal of the Asian Studies Association of Australia 36-2:207-26, 2012.

Johnson, G. 'Authenticity, invention, articulation: Theorizing contemporary Hawaiian traditions from the outside', Method \& Theory in the Study of Religion 20-3:243-58, 2008.

Jones, A.F. Yellow music: Media culture and colonial modernity in the Chinese jazz age. Durham/London: Duke University Press, 2001.

Jurriëns, E. Cultural travel and migrancy: The artistic representation of globalization in the electronic media of West Java. Leiden: KITLV Press, 2004.

Kahn, J.S. Modernity and exclusion. London: SAGE, 2001.

_ _ . 'Islam, modernity, and the popular in Malaysia', in: V. Hooker and N. Othman (eds), Malaysia: Islam, society and politics, pp. 149-66. Singapore: Institute of Southeast Asian Studies, 2003.

Keppy, P. 'Keroncong, concours and crooners. Home grown entertainment in twentiethcentury Batavia', in: P. Boomgaard, D. Kooiman and H. Schulte Nordholt (eds), Linking destinies. Trade, towns and kin in Asian history, pp. 141-58. Leiden: KITLV Press, 2008.

Koh, K.W. 'A Chinese Malaysian in Taiwan: Negarakuku and a song of exile in the diaspora', Studies in Ethnicity and Nationalism 8-1:50-79, 2008.

Kong, L. 'Music and cultural politics: Ideology and resistance in Singapore', Transactions of the Institute of British Geographers 20-4:447-59, 1995.

Laird, L. The Singapore record industry in the 196os'. Paper presented at the international conference 'The Beat Goes On: Popular Music in Twentieth Century Southeast Asia', organized by KITLV, Jakarta, 10-11 January, 2011.

Leland, J. Hip, the history. New York, NY: Harper Perennial, 2005.

Lindblad, J.T. Bridges to new business. The economic decolonization of Indonesia. Leiden: KITLV Press, 2008.

Lindsay, J. 'Making waves: Private radio and local identities in Indonesia', Indonesia 64:105-23, 1997.

Lipsitz, G. Footsteps in the dark: The hidden histories of popular music. Minneapolis, MI: University of Minnesota Press, 2007.

Lockard, C.A.Dance of life: Popular music and politics in Southeast Asia. Honolulu, HI: University of Hawai'i Press, 1998.

Luvaas, B. 'Designer vandalism: Indonesian indie fashion and the cultural practice of cut 'n' paste', Visual Anthropology Review 26-1:1-16, 2010.

Manuel, P.L. Cassette culture: Popular music and technology in North India. Chicago: University of Chicago Press, 1993.

Marcus, G. Lipstick traces: A secret history of the twentieth century. Cambridge, MA: Harvard University Press, 1989 .

McVey, R. 'Globalization, marginalization, and the study of Southeast Asia', in: C.J. Reynolds and R. McVey (eds), Southeast Asian studies: Reorientations, pp. 37-64. Ithaca, New York, NY: Cornell University, 1998.

Middleton, R. Studying popular music. Milton Keynes, UK: Open University Press, 1990.

Miles, S. Youth lifestyles in a changing world. Buckingham, UK: Open University Press. 
Milner, A.C., 2000.

-. The Malays. Malden, MA: Wiley-Blackwell, 2008.

Mitchell, J. 'Red and yellow songs: A historical analysis of the use of music by the United Front for Democracy against Dictatorship (UDD) and the Peoples' Alliance for Democracy (PAD) in Thailand', South East Asia Research 19-3:457-94, 2011.

T. Mitchell. 'Self-Orientalism, reverse-Orientalism and pan-Asian flows in Dick Lee's Transit Lounge, in': Iwabuchi, K., S. Muecke and M. Thomas (eds), Rogue flows: transAsian cultural traffic, pp. 95-118. Hong Kong: Hong Kong University Press, 2004.

Möller, A.J.M. Batavia, a swinging town!: Dansorkesten en jazzbands in Batavia 1922-1949. Den Haag: Moesson, 1987.

Mokoo, A. Nyanyian di tengah kegelapan: Pembicaraan singkat lirik lagu Iwan Fals. Yogyakarta: Ombak, 2003.

Moore, A. 'What story should a history of popular Music tell?', Popular Music History 1-3:329-38, 2006.

Mrázek, R. Engineers of happy land. Technology and nationalism in a colony. Princeton: Princeton University Press. [Princeton Studies in Culture/Power/History], 2002.

Müller, D.M. 'Islamism, youth and the contestation of normative orders: A study on dewan pemuda PAS, the youth wing of the Islamic Party of Malaysia (PAS)'. Inaugural dissertation, Frankfurt am Main, Johann-Wolfgang-Goethe-Universität, 2012.

Mutsaers, L. "Barat ketemu timur": Cross-cultural encounters and the making of early kroncong history', in: Bart Barendregt and Els Bogaert (eds), Recollecting resonance: Indonesian Dutch musical encounters, pp. xx. Leiden: Brill, 2013.

Naafs, S. and B. White. 'Intermediate generations: Reflections on Indonesian youth studies', The Asia Pacific Journal of Anthropology 13-1:3-20, 2012.

Oliver, P. 'History begins yesterday', Popular Music History 1:15-7, 2004.

Pereira, J.C. Apache over Singapore: The story of Singapore sixties music, volume one. Singapore: Select Publishers, 2011.

Pickles, J. 'Of purple hair and protest: Beyond spectacular style, Bandung punks take collective action'. MA thesis, Canberra, Faculty of Asian Studies, Australian National University, 2001.

Pinches, M. Culture and privilege in capitalist Asia. London: Routledge, 1999.

Piper, S. and S. Jabo. 'Musik Indonesia, dari 1950-an hingga 1980-an', Prisma 5-16:8-23.

Rafael, V.L., 1987.

—. 'Taglish, or the phantom power of the lingua franca', Public Culture 8:101-26, 1995.

Samuel, R. People's history and socialist theory. London: Routledge and Paul Kegan, 1981.

Sarji, Ahmad and S. Johari. Lagu-lagu filem P. Ramlee 1961-1972. Kuala Lumpur: Harvard Kelab Di Malaysia, 1995.

Sarkissian, M. "Religion never had it so good": Contemporary "nasyid" and the growth of Islamic popular music in Malaysia', Yearbook for Traditional Music 37:124-52, 2005.

Scherer, S. 'Tuna karya, jilbab and cow-boy hat: Youth in Suharto's Indonesia as reflected in the works of Remy Sylado and Emha Ainun Nadjib', Indonesia and the Malay World 34: 197-211, 2006.

Schmidt, V. 'Modernity and diversity: Reflections on the controversy between modernization theory and multiple modernists', Social Science Information 49-4:511-38, 2010.

Schulte Nordholt, H. 'Onafhankelijkheid of moderniteit? Een geillustreerde hypothese', in: M. Bloembergen en R. Raben (eds), Het koloniale beschavingsoffensief. Wegen naar het nieuwe Indië, 1890-1950, pp. 105-20. Leiden: KITLV, 2009.

—. 'Modernity and cultural citizenship in the Netherlands Indies: An illustrated hypothesis', Journal of Southeast Asian Studies 42-3:435-57, 2011.

Sen, K. and D.T. Hill. 'Global industry, national politics: Popular music in "New Order" Indonesia', in: A.J.U.L Chun, N. Rossiter and B. Shoesmith (eds), Refashioning pop music in Asia: Cosmopolitan flows, political tempos, and aesthetic industries, pp. 74-88. London: RoutledgeCurzon, 2004. 
Shim, D. 'Hybridity and the rise of Korean popular culture in Asia', Media, Culture \& Society 28-1:25-44, 2006.

Siegel, J.T. Solo in the New Order: Language and hierarchy in an Indonesian City. Princeton, NJ: Princeton University Press, 1993.

Siriyuvasak, U. and S. Hyunjoon. 'Asianizing K-pop: Production, consumption and identification patterns among Thai youth', Inter-Asia Cultural Studies 8-1:109-36, 2007.

Small, C. Musicking: The meanings of performing and listening. Middletown, CT: Wesleyan University Press, 1998.

Smith-Hefner, N.J. 'Youth language, gaul sociability, and the new Indonesian middle class', Journal of Linguistic Anthropology 17-2:184-203, 2007.

Steedly, M. 'The state of culture theory in the anthropology of Southeast Asia,' Annual Review of Anthropology 29:89-106, 2000.

Storey, J. Inventing popular culture: From folklore to globalization. Malden, MA: Blackwell, 2003.

Suryadi. 'Minangkabau commercial cassettes and the cultural impact of the recording industry in West Sumatra', Asian Music 34-2:51-89, 2003.

— . "The "talking machine" comes to the Dutch East Indies: The arrival of western media technology in Southeast Asia', Bijdragen tot de Taal-, Land- en Volkenkunde 162-2/3:269305, 2006.

Sushartami, W. 'Representation and beyond: Female victims in post-Suharto media'. $\mathrm{PhD}$ Thesis, Leiden, Leiden University, 2012.

Sutton, R.A. 'Who Is the pesindhèn? Notes on the female singing tradition in Java', Indonesia 37:118-33, 1984.

- . Interpreting electronic sound technology in the contemporary Javanese soundscape', Ethnomusicology: Journal of the Society for Ethnomusicology 40:249-68, 1996.

-. 'Local, global, or national: Popular music on Indonesian television', in: L. Parks and

S. Kumar (eds), Planet TV: A global television reader, pp: 320-41. New York: New York University Press, 2003.

Syed Muhd Khairudin Aljunied. 'Films as social history - P. Ramlee's "Seniman Bujang Lapok" and Malays in Singapore (1950s-6os), The Heritage Journal 2-1:1-21, 2005.

Tan, J. Popular music in 1960s Singapore. Biblioasia 7-1:10-15, 2011.

Tan, S.B. Bangsawan. A social and stylistic history of popular Malay opera. Singapore. Oxford University Press, 1993.

—. 'The $78 \mathrm{rpm}$ record industry in Malaya prior to World War II', Asian Music 28:1-41, 1996.

_. 'From folk to national popular music: Recreating ronggeng in Malaysia', Journal of Musicological Research 24:3-4, 2005.

Taylor, J.G. 'The sewing-machine in colonial-era photographs: A record from Dutch Indonesia', Modern Asian Studies 46-1:71-95, 2012.

Turner, V.W. Dramas, fields, and metaphors: Symbolic action in human society. Ithaca: Cornell University Press. [Symbol, Myth, and Ritual Series.] 1974.

Tyson, A.D. 'Titik api: Harry Roesli, music, and politics in Bandung, Indonesia', Indonesia 91:1-34, 2011.

Wagner, P. Modernity: Understanding the present. Cambridge: Polity, 2012.

Wallach, J. 'Exploring class, nation, and xenocentrism in Indonesian cassette retail outlets', Indonesia 74:79-102, 2002.

—. Modern noise, fluid genres: Popular music in Indonesia, 1997-2001. Madison: University of Wisconsin Press, 2008.

- . 'Unleashed in the East: Metal music, masculinity, and "Malayness" in Indonesia, Malaysia and Singapore', in: J. Wallach, H.M. Berger and P.D. Greene (eds), Metal rules the globe: Heary metal music around the world, pp. 86-108. Durham, NC: Duke University Press, 2011.

Wee, C.J.W.L. 'Staging the new Asia: Singapore's Dick Lee, pop music and a counter modernity', Public Culture 8-3:489-510, 1996. 
Weidman, A. 'Guru and gramophone. Fantasies of fidelity and modern technology of the real', Public Culture 15-3:453-76, 2003.

Weinbaum A.E. et al (eds). The modern girl around the world. Consumption, modernity and globalization. Durham/ London: Duke University Press, 2008.

Weintraub, A.N. 'Dangdut soul: Who are "the people" in Indonesian popular music?', Asian Journal of Communication 16-4: 411-31, 2006.

. Dangdut stories: A social and musical history of Indonesia's most popular music. New York, NY: Oxford University Press, 2010.

Wichelen, S. van. Religion, politics and gender in Indonesia: Disputing the Muslim body. Milton Park, Abingdon, Oxon: Routledge. [Routledge Research on Gender in Asia Series.] 2010.

Williams, R. Keywords: A vocabulary of culture and society. New York: Oxford University Press, 1976.

- Culture and society, 1780-1950. London: Penguin, 1984.

Williams, S. 'Current developments in Sundanese popular music', Asian Music 21-1:105-36, 1990.

—. 'Constructing gender in Sundanese music', Yearbook for Traditional Music 30:74-84, 1998.

Williamson, J. and M. Cloonan. 'Rethinking the music industry', Popular Music 26-2: 305-22, 2007.

Worden, N. "Where it all began"': The representation of Malaysian heritage in Melaka', International Journal of Heritage Studies 7-3:199-218, 2001.

Yampolsky, P. 'Hati yang luka", an Indonesian hit', Indonesia 47:1-17, 1989.

. 'Can the traditional arts survive, and should they?', Indonesia 71:175-85, 2001.

. 'Kroncong revisited: New evidence from old sources', Archipel 79:7-56, 2010.

Yusof, Azmyl Md. 'Facing the music: Musical subcultures and "morality" in Malaysia', in: S.G. Yeoh (ed.), Media, culture and society in Malaysia, pp. 179-96. London: Routledge, 2010. 